\title{
sazonalidade e trabalho temporário na empresa cafeeira (oeste paulista, 1890-1915)
}

\author{
Cláudia Alessandra Tessari $\star \star$ \\ Professora do curso de Ciências Econômicas da Universidade Federal de São Paulo - UNIFESP, \\ Campus Osasco
}

RESUMO

Este texto tece relações entre o trabalho temporário e a gestão da empresa cafeeira no Oeste Velho paulista entre 1890 e 1915. Uma importante característica da atividade econômica na agricultura é a sazonalidade e a inconstância na demanda por trabalho. Essa característica leva à necessidade de utilização de mão de obra temporária para as tarefas que são sazonais, a fim de possibilitar a adequada gestão dos custos da empresa agrícola. Sabe-se que, a partir de meados da década de 1950, o trabalho temporário é exacerbado na lavoura paulista, com o advento do trabalho volante. Este artigo estuda o trabalho temporário, portanto, num período anterior à sua exacerbação. Defende a ideia de que o sistema de trabalho que se seguiu à escravidão nas fazendas de café em São Paulo deve ser pensado como uma associação entre colonato e trabalho temporário sazonal, sendo este último também importante para estruturar a atividade produtiva e não uma categoria de trabalho marginal, como parte da bibliografia costuma classificá-lo. Nossa

\section{Abstract}

This article depicts the temporary labor in the São Paulo coffee fields post Slavery Abolition years in Brazil. A relevant attribute of the economic rural activity at that point in time was the intermittent work throughout the agricultural year. There were periods of high and low demand of workers, depending on the task to be performed, which in turn, was dependant on the life cycle of the cultivated plant (time to prepare the land, planting, harvesting, etc.). The intermittent work lead to another important attribute of the rural work of that time: the advent of the temporary labor. Starting in mid 1950's, the temporary labor becomes widespread in the Sao Paulo coffee fields with the expansive temporary non-resident workers ("volante" workers). This presentation will study the temporary work prior to its becoming prevalent, yet on a period where it was already important, along with the "colonato" system, to structure the economic rural activity in Sao Paulo. The hypothesis is that the arrangement of "colonato" system plus

* Submetido: outubro, 2011; aceito: dezembro, 2011.

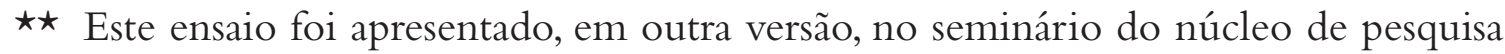
Hermes \& Clio, da USP, em 28 de setembro de 2011. Email: ctessari@gmail.com. 
tese é que esse arranjo (colonato + trabalho temporário sazonal) permitiu que a empresa rural cafeeira driblasse o problema da rigidez da mão de obra frente à sazonalidade da agricultura, garantindo possibilidade de flexibilidade dos fatores de produção e dos custos com trabalho.

Palavras-chave: Trabalho temporário. Colonato. Sazonalidade. Transição escravidão. São Paulo. temporary work helped the Coffee Farming units minimizing the problems concerning the workforce demand planning for the rural activity, which was characteristically cyclical and intermittent, allowing the Sao Paulo Coffee Farming to initiate a management in the typical capitalist mode.

Keywords: Temporary labor. Colonato. Agricultural seasonality. Transition slavery. Sao Paulo.

\section{Introdução}

Este texto tem o objetivo de estudar o trabalho temporário, seja dentro do sistema de colonato, seja em associação a ele, como forma de trabalho estruturante da atividade cafeeira no Oeste Velho paulista durante a formação do mercado de trabalho, entre 1890 e 1915.

Em 1888, é abolida a escravidão no Brasil, pondo fim ao processo gradual de emancipação dos escravos que vinha ocorrendo desde a década de 1870. No ano seguinte à Abolição, 1889, há a mudança de regime político e, com ela, a descentralização do poder e a maior autonomia dos estados. Com as mudanças proporcionadas pela Constituição de 1891 e as alterações fiscais dela advindas, o Estado de São Paulo se diferenciou perante os demais em função da riqueza gerada pelo complexo cafeeiro. São Paulo passou a contar com recursos fiscais provenientes das exportações e, por isso, pôde financiar integralmente a imigração (COSTA, 1998). Juntamente com a imigração, foi fundamental para a expansão cafeeira o desenvolvimento das linhas ferroviárias que permitiram o barateamento dos transportes e a livre movimentação de mercadorias e mão de obra.

Em 1915, com a Primeira Guerra Mundial, há a diminuição da imigração para o Brasil. É a partir desse momento que os fazendeiros paulistas, unidos à classe intelectual da época (jornalistas e escritores) deram início a um processo de revalorização do trabalhador nacional, seja nos discursos sobre suas qualidades e defeitos, seja nas maneiras de tornar possível sua utilização como mão de obra, em contraposição à mudança no discurso em relação ao imigrante estrangeiro (KOWARICK, 1987; SALLES, 1995; NAXARA, 1998). É nesse período também que o 
trabalhador nacional passa a ser mais sistematicamente utilizado no trabalho regular agrícola ou urbano (BASTIDE e FERNANDES, 1959; KOWARICK, 1987; SANTOS, 2003). Também é nesse momento que a migração interna passa a aumentar consideravelmente.

Apesar do recorte cronológico se limitar a 1890-1915, a questão tratada neste artigo dialoga com um período mais amplo, visto que parte do problema aqui analisado, a sazonalidade da agricultura frente à rigidez da mão de obra, já existia desde a época da escravidão. Dialoga também com um período posterior ao aqui recortado. A partir dos anos 1960, tornou-se visível, no campo brasileiro, o fenômeno do chamado "trabalhador volante": o "boia-fria" do Paraná e São Paulo; o "pau-dearara" de algumas áreas de São Paulo; e o "clandestino" da zona canavieira de Pernambuco. Esses trabalhadores agrícolas residem fora das fazendas, em geral nas periferias das cidades e vilas, e se deslocam continuamente para executar tarefas, em regime de empreitada, nas áreas rurais (MELLO, 1976; GRAZIANO, 1981; GONZALES e BASTOS, 1982).

Este movimento de avanço e recuo no tempo permite que se aponte para uma interpretação mais ampla sobre as formas de trabalho que foram sendo realizadas historicamente e que permitiram ao capital o uso flexível - e atendendo às suas necessidades - do fator trabalho. Num extremo temos a rigidez do trabalho escravo. No outro, a "flexibilização" permitida pelo trabalho volante a partir da década de 1960. O que analisamos, portanto, é um período que pode ser caracterizado como de transição. Transição entre uma forma de quase total rigidez do trabalho e uma forma de quase plena flexibilização.

Para estudar as questões propostas neste artigo, recortou-se o Oeste Velho paulista, região com menores propriedades rurais e mais policultores quando comparada com as regiões de fronteira do café. Para desvendar a participação efetiva do trabalhador temporário, utilizaram-se jornais de dois municípios desta região: Piracicaba e Itu.Ambos guardam semelhanças e diferenças entre si. No tocante às semelhanças, os dois municípios receberam pequena corrente imigratória quando comparados com as áreas do chamado Oeste Novo, e ambos pertenciam às áreas de povoamento mais antigo da província/estado, sendo, por isso, populosos e tendo grande presença de população nacional (branca, mestiça e negra). Quanto às atividades econômicas, o café conviveu na região em grau de importância com a cana-de-açúcar e o algodão (CA- 
NABRA e MENDES, 1938; MILLIET, 1982; RAMOS, 2001). Além das culturas comerciais (como eram chamadas na documentação da época as lavouras cafeeira, canavieira e algodoeira), ambos os municípios produziam largamente os cereais (como eram chamadas pela documentação as culturas alimentares: milho, feijão e arroz, por exemplo) (REPARTIÇÃO DE ESTATÍSTICA, 1907: 57-60).

Estas características - policultura, alta densidade populacional, cafeeiros menos produtivos e menor capacidade de atração da corrente imigratória - tornavam esses locais mais propícios à utilização de mão de obra não colona, por isso a documentação da região é fonte privilegiada para o estudo aqui proposto.

\section{Sazonalidade e incerteza na agricultura e na lavoura cafeeira}

Uma característica marcante do trabalho na agricultura é sua instabilidade e incerteza. Seja ao longo do ano agrícola, seja de um ano para outro, a demanda por trabalho tem grandes oscilações. Em determinados momentos do ano agrícola, determinadas tarefas têm de ser efetuadas; em outros momentos, outras tarefas não podem ser executadas sob o risco de a planta cultivada ser perdida ou não render bons frutos, como por exemplo, uma plantação fora do tempo ideal, cuja germinação pode coincidir com momentos de calor intenso, danificando a plantação: "Essas coisas [plantar, colher, capinar, derrubar árvores, castrar animais] devem ser feitas no devido tempo para que surtam o efeito desejado" (SOBRINHO, 1906: 21)

No final do século XIX e início do XX, no Brasil, a produção agrícola era ainda extremamente dependente das determinações naturais, visto que eram inexistentes as inovações químicas e genéticas que viriam alterar de certa forma o ciclo de cultivo ou a demanda por trabalho (como o uso de herbicidas, que viria diminuir a necessidade de mãode-obra na capinação) (SILVA, 1981:33; BRANT, 1977: 75). Essa extrema dependência implicava uma alta sazonalidade na demanda por mão-deobra na agricultura, condicionando momentos de mais trabalho ou de menos trabalho e, até mesmo, momentos de vacância (quando praticamente não se trabalhava). 
Em geral, os trabalhos na agricultura podem ser divididos em quatro etapas: 1) preparação do solo (quando se prepara a terra para a plantação); 2) plantação propriamente dita (por meio de sementes ou mudas); 3) trato ou cultivo (cuidados durante o crescimento e amadurecimento da planta); e 4) corte ou colheita do fruto amadurecido. Cada uma dessas etapas requer tipos diversos de tarefas que devem ser realizados com ritmos e quantidade de trabalho diferentes. No geral, a etapa do corte ou colheita é a que requer trabalho mais intenso, tanto em quantidade de trabalho quanto em ritmo. Depois do corte ou colheita, a etapa que requer mais trabalho é a plantação. Por outro lado, a etapa do cultivo é, em geral, a que requer menos trabalho.

A análise dos Calendarios Agricolas Paulistas, publicados nos Almanaques Agrícolas e nos Boletins de Agricultura do final do século XIX e início do $\mathrm{XX}$, mostrou-nos a existência de duas estações bem marcadas: 1) estação fria ou seca; e 2) estação quente ou chuvosa. Evidenciou-nos também que essas duas estações concentravam atividades que requeriam necessidades díspares de mão de obra.

A estação fria ou seca, que em São Paulo vai de abril a setembro, era a estação de trabalho mais intenso, pelo fato de nela ocorrerem as colheitas dos produtos comerciais paulistas do período (café e cana-de-açúcar). Além do mais, o trabalho intenso exigia maior quantidade de mão de obra, exigindo também que o trabalho fosse feito em velocidade maior, pois, em geral, há um intervalo de tempo bem definido dentro do qual o fruto maduro deve ser colhido e beneficiado:

[em abril] os fazendeiros de café devem abandonar tudo para colherem o café despolpado, porque há lugares em que o café amadurece de uma vez, e então torna-se impossível despolpar mais da metade da colheita; o resto só fica preparado como café ordinário que se vende pela metade ou dous terços do café lavado (CALENDARIO AGRICOLA, 1869: 49).

Além da colheita, plantação e beneficiamento, aquele era também o momento adequado para o transporte das mercadorias produzidas nas fazendas e sítios, que deviam ser transportadas rapidamente porque as estações chuvosas provocavam enchentes e alagamentos nas estradas de rodagem, dificultando o transporte das mercadorias ou tornando as estradas intransitáveis (CAMARGO, 1923: 20). 
$\mathrm{Na}$ estação seca também deviam acontecer as mais diversas atividades não agrícolas do mundo rural, tais como os consertos e construções das instalações das propriedades, das estradas e dos caminhos: "São trabalhos que devem ser feitos logo, neste mês: a limpa dos pastos, a reparação das cercas, a limpeza dos tapumes [...]" (SOBRINHO, 1906: 23). As obras públicas deveriam ser efetuadas preferencialmente nessa época do ano. A Superintendência de Obras Públicas do Estado de São Paulo, em oficio pelo qual autorizava os consertos da estrada de rodagem que ligava a Freguesia da Água Branca à do Ò, ressalvava: "mas elles só deverão ser executados em tempo de seca, porque o tempo chuvoso não só dificulta o trabalho como também peiora as condições da estrada [...]" (OFICIO DA SUPERINTENDENCIA DE OBRAS PÚBLICAS, 1890)

Era nessa época, também, que devia acontecer a castração de animais, visto que a pouca umidade dificultava a proliferação de moscas e mosquitos e tornava mais fácil a cicatrização: "Julho é mês proprio para corte de madeira e castração de animais da fazenda, sobretudo porcos..." (SOBRINHO, 1906: 25).

Como a etapa da plantação deveria acontecer em setembro, o preparo da terra para o plantio dos mais diversos vegetais, inclusive dos pés de café, acabava coincidindo também com o período de colheita e beneficiamento, que em São Paulo ocorria entre abril e setembro. A derrubada das matas e queima, tarefas que antecediam a plantação dos novos cafezais, eram, portanto, realizadas também nesse período: "A época das roçadas deverá ser o periodo da sêca, isto é, quando as chuvas não possam atrapalhar esse serviço nem difficultar a queima. Prefere-se, em geral, o periodo de Maio a Agosto" (RAMOS, 1923: 89).

Temos, portanto, que na estação fria ou seca (de abril a setembro) a demanda por trabalho era intensa. Nesse período, coincidiam as fases de colheita, plantação e o preparo do solo dos principais produtos cultivados em grande escala na lavoura paulista (café e cana-de-açúcar). Coincidiam também a castração dos animais, o beneficiamento e transporte dos produtos colhidos, os consertos e construções.

Por outro lado, na estação quente ou das águas (de outubro a março), o trabalho a ser realizado era bem menor. Em outubro, quando tinha início a estação quente, o trabalho começava a diminuir, atingindo o nível mais baixo de necessidade de mão de obra nos meses de novembro, 
dezembro e janeiro, pois nesse período o calor era intenso e as chuvas tornavam inviáveis diversos trabalhos:

Bem poucos são os serviços culturaes que se praticam neste mez. Não se fazem mais colheitas; as roçadas já não são possíveis; restam apenas os trabalhos de capina e alguma semeadura atrasada (...) a plantação de novembro é condemnavel por dois motivos principaes: em primeiro logar, a maturação corre risco de ser prejudicada pelo frio do outono e depois os trabalhos são muito mais custosos e incertos, devido á persistencia das chuvas. (...) Novembro é mau mez para chocar galinhas e castrar animais domésticos (SOBRINHO, 1906: 28-29).

No entanto, se a maior parte das atividades devia acontecer no tempo seco e não na estação quente ou das águas, a lavoura de cereais (como eram chamadas as lavouras alimentares, tais como feijão, milho, batata e arroz), contrariamente, concentrava seu ciclo de produção nessa época do ano: "O único serviço que tem plena atividade neste mez [março] é a colheita de cereaes, cultivados pela rotina" (SOBRINHO, 1906: 29-30).

Como as chuvas faziam crescer mato e erva daninha, era também nesse período do ano que ocorriam as capinas nas lavouras comerciais de café e cana-de-açúcar, atividade importante, porém menos exigente em mão de obra: "[...] a capina ou carpa é a única operação cultural que tem justo cabimento no mez de Novembro" (SOBRINHO, 1906: 28-29).

Portanto, quando observamos os calendários das mais diversas qualidades de plantas cultivadas no Oeste Paulista em fins do século XIX e início do XX, percebemos que as demandas sazonais por trabalho que cada planta implicava, quando sobrepostas, faziam que num período específico do ano (na estação fria ou seca) houvesse bem maior demanda por trabalho enquanto no outro período (estação quente ou chuvosa) a demanda fosse bem menor.

Outro dado importante é que, quando comparamos os momentos de pico de trabalho nas lavouras comerciais (café e cana-de-açúcar) com os momentos de mais trabalho nas lavouras de alimentos, percebemos que os períodos de maior demanda por trabalho eram intercalares entre si. Os três meses de trabalho vago na lavoura de alimentos 
(maio, junho e julho) coincidiam justamente com os meses de trabalho intenso na cafeicultura, na lavoura canavieira e nas benfeitorias e nos transportes.

\section{Inconstância do trabalho no café}

O trabalho nos cafezais obedecida várias etapas. A primeira delas consistia na plantação do cafezal, que era feita apenas uma vez e cuja planta, já transformada em arbusto, durava décadas. Ela era necessária apenas quando da abertura de novas fazendas ou de novas áreas dentro de fazendas já constituídas e consistia, primeiramente, na derrubada da mata virgem. Paralelamente à derrubada criavam-se os "viveiros" de café para a formação de mudas. No todo, tal atividade se estendia entre março e agosto: entre março e abril, ocorria a derrubada da mata; em maio, junho e parte de julho, deixavam-se secar as árvores abatidas e formavam-se os viveiros de mudas; em parte de julho e agosto, antes do início da estação chuvosa, fazia-se a queimada (ALVIM, 1986: 78).

Para as fazendas já constituídas e produtivas (em geral com cafeeiros com mais de quatro anos) a atividade de produção era dividida nas etapas de capina, colheita e beneficiamento do café colhido. A primeira etapa, a capina ou carpição do terreno, era realizada em média cinco vezes no período entre uma colheita e outra, e consistia em arrancar os capinzais e ervas daninhas com a enxada e com as mãos. Se entre uma colheita e outra devia ser feita em média cinco capinas e se cada trabalhador costumava cuidar de mais de dois mil pés, o trabalho de capinar acabava por ser o mais contínuo ao longo do ano agrícola, que costumava durar de outubro a setembro. (DAVATZ, 1980: 65; BOLETIM DO DEPARTAMENTO ESTADUAL DO TRABALHO, 1912: 21).

O momento da colheita era o que exigia maior número de trabalhadores, não só porque a tarefa em si exigia mais, mas porque nesse momento deviam ser realizadas várias outras tarefas. Ao mesmo tempo em que a colheita era realizada, eram requeridos os trabalhos de transporte e os de beneficiamento do fruto colhido. Os trabalhos de transporte incluíam o carregamento dos carros nos campos, o transporte do café dos campos até o terreiro, do terreiro às máquinas onde os frutos seriam beneficiados e, depois, das fazendas até a estação de trem mais 
próxima. As tarefas de beneficiamento incluíam a secagem nos terreiros onde o café seria espalhado ao sol para secar. Por alguns dias seguidos, o café seria mexido com o rodo várias vezes diariamente, amontoado e coberto no final do dia, até que estivesse seco e pudesse ser transportado às máquinas para beneficiamento. $\mathrm{O}$ período da colheita, que durava de maio a agosto, era, portanto, o de maior demanda de trabalho: "É excusado dizer que a colheita do café constitue a grande faina da época [...] Isto quer dizer que se povoam os terreiros..." (BOLETIM DA AGRICULTURA, 1906: 193).

Após o beneficiamento, o café devia ser ensacado e transportado até as estações ferroviárias mais próximas. $\mathrm{O}$ ano agrícola era dado por terminado quando, finda a colheita, acontecia o espalhamento do cisco (ou a última capina).

A alternância entre épocas de trabalho intenso, épocas de menos trabalho e momentos de não trabalho causa uma característica muito peculiar à atividade agrícola: a diferença entre o tempo de trabalho e o tempo de produção. O tempo de trabalho é a quantidade de tempo que o trabalhador dedica às tarefas do processo de produção (preparar a terra, plantar, cultivar e colher), enquanto o tempo de produção é a quantidade de tempo necessária para que o produto esteja pronto.

No caso do café, em 1888 estimava-se que o trabalhador gastaria 175 dias para tratar e colher o fruto. Esses 175 dias teriam de estar distribuídos em meio aos 360 dias decorridos entre uma colheita e outra. Conclusão: o tempo de trabalho era de 175 dias, o tempo de produção era de 360 e o tempo de não trabalho (tempo de vacância, também chamado tempos mortos do café) era de 185 dias (GAZETA DE PIRACICABA, 14 de agosto de 1888).

Nas fazendas em que havia áreas de café em formação paralelamente às áreas já produtivas, a demanda por trabalho era ainda mais acentuada nessa época, pois o desmatamento e o plantio deviam ocorrer no mesmo momento da colheita. Haveria de existir, portanto, trabalhadores em quantidade suficiente para que todas essas tarefas fossem executadas ao mesmo tempo. No entanto, na estação quente ou chuvosa, parte importante desses trabalhadores ficava sem trabalho.

Além da sazonalidade típica dos ciclos das plantas, outro fator a determinar a inconstância da demanda por mão-de-obra era a incerteza 
quanto às colheitas, pois elas podiam variar muito de um ano para outro. Davatz, em 1850, chegava a afirmar que a diferença de produtividade de um ano para outro era muito considerável, sendo que "a mesma árvore, em um mau ano, produz quando muito a quarta parte do que dá em um ano feliz". (DAVATZ, 1980: 65; ver também HOLLOWAY, 1984: 119).

O regime pluvial do clima tropical de São Paulo, com suas chuvas irregulares, era um agravante para a inconstância das colheitas, que ficavam ainda mais prejudicadas nas áreas de povoamento mais novo:

Os planaltos ocidentais de São Paulo e os do norte do Paraná apresentam em toda a sua extensão [...] um regime pluviométrico de tipo tropical indiscutível. Certamente, como sempre acontece, esse regime é acompanhado pela irregularidade das chuvas e também das colheitas. O fazendeiro se compraz em afirmar, com pessimismo bem camponês, que em vinte anos não há senão quatro boas colheitas de café (MONBEIG, 1984: 62, grifo do autor).

A lavoura cafeeira, portanto, apesar de exigir certa quantidade de mão de obra permanente (para os tratos culturais ou capinas), ainda assim mantinha diferenças significativas quanto às exigências de trabalho ao longo do ano agrícola: "O segundo embaraço resulta do desequilíbrio entre o número de trabalhadores necessários para o tratamento dos cafezaes e o reclamado pelos trabalhos das colheitas; este último muito maior" (RAMOS, 1923: 104).

Como pode ser observado na Tabela 1 , que transcreve na íntegra dados publicados no Boletim da Agricultura em 1900, para o período da colheita eram necessários, em média, 54\% mais trabalhadores (representados pela quinta coluna na tabela $)^{1}$.

1 Esses dados assemelham-se com os apontados por Caminhoá, que mostrou que o número de trabalhadores que iam para a lavoura continuamente era de, em média, 61\% do total de trabalhadores escravos (CAMINHOÁ, 1880: várias páginas). Assemelham-se também com dados de Bassanezi, que mostram que os colonos representavam pouco mais da metade do total de trabalhadores da fazenda Santa Gertrudes entre 1895 e 1930 (BASSANEZI, 1975: 246). 
Tabela 1 - Número de trabalhadores necessários para as fazendas de café (permanentes e temporários)

\begin{tabular}{|c|c|c|c|c|c|c|}
\hline \multirow[t]{3}{*}{ Municípios } & \multirow{3}{*}{$\begin{array}{c}\begin{array}{c}\text { FAZENDAS } \\
\text { DE CAFÉ }\end{array} \\
\begin{array}{c}\text { Número } \\
\text { total }\end{array}\end{array}$} & \multicolumn{3}{|c|}{ TRABALHADORES } & \multicolumn{2}{|c|}{ TOTAL DE PÉS DE CAFÉ } \\
\hline & & $\begin{array}{c}\text { Existentes } \\
\text { no momento }\end{array}$ & $\begin{array}{l}\text { Necessários } \\
\text { para completo }\end{array}$ & $\begin{array}{c}\text { Extra } \\
\text { necessários }\end{array}$ & \multirow[t]{2}{*}{$\begin{array}{l}\text { Maiores } \\
\text { de } 4 \text { anos }\end{array}$} & \multirow[t]{2}{*}{$\begin{array}{l}\text { Menores } \\
\text { de } 4 \text { anos }\end{array}$} \\
\hline & & pesquisa & $\begin{array}{l}\text { funcionamento } \\
\text { da propriedade }\end{array}$ & $\begin{array}{l}\text { no tempo } \\
\text { da colheita }\end{array}$ & & \\
\hline Araçariguama & 11 & 66 & 100 & 147 & 135.900 & 9.000 \\
\hline Atibaia & 249 & 1.806 & 2.251 & 2.784 & 2.308 .600 & 2.506 .600 \\
\hline Bananal & 111 & 1.753 & 2.027 & 2.589 & 4.071 .700 & 551.800 \\
\hline Pilar & 10 & 45 & 70 & 154 & 84.500 & 5.000 \\
\hline Sertãozinho & 60 & 9.594 & há falta & 2.810 & 7.345 .388 & 4.410 .600 \\
\hline
\end{tabular}

Fonte: "Estatística especial da lavoura de café nos municípios de Araçariguama, Atibaia, Bananal, Pilar, Sertãozinho e Redempção" in Boletim de Agricultura. São Paulo: Typographia do Diario Official, 1900 , n.6 (suplemento)

Além das atividades diretas necessárias para a carpição, colheita e beneficiamento do café, a manutenção de uma fazenda cafeeira exigia outras tantas atividades para seu pleno funcionamento: trabalhos de conserto das instalações, trabalho nas serrarias, carpintaria, ferraria de animais, olaria, pessoal para o cuidado com os currais dos animais de tração, etc. A manutenção de toda a empresa agrícola cafeeira exigia, assim, os mais variados tipos de trabalho, que deveriam ser executados em momentos diferentes do ano e que exigiam também diferentes quantidades de trabalhadores. Era necessário certo número de pessoal permanente para o trabalho regular de capina dos cafezais; um outro número de trabalhadores temporários para as tarefas diversas da fazenda; outro número, maior ainda, para a colheita e beneficiamento do café. Cada atividade, dependendo das tarefas requeridas, do tempo necessário para efetuá-la e do número de trabalhadores necessários correspondia a um determinado sistema de trabalho.

\section{A rigidez da mão de obra}

As características especiais do trabalho agrícola (a inconstância da demanda por mão de obra e a dificuldade de se estimar ao certo e antecipadamente o número de trabalhadores necessários para a colheita) 
determinaram, em momentos históricos diferentes, diferentes relações de trabalho. No Brasil, durante a escravidão, elas implicaram na autosuficiência das fazendas, maneira encontrada para manter a mão de obra ocupada ao longo de todo o ano. $\mathrm{Na}$ transição da escravidão para o trabalho livre, em São Paulo, a partir de 1880, implicou uma configuração especial de trabalho nas principais lavouras comerciais: o colonato associado ao trabalho temporário sazonal. Essas relações de trabalho irão perdurar por toda a primeira metade do século XX com pequenas modificações, quando então o sistema de colonato será praticamente substituído pelo trabalho volante (trabalho temporário de não residentes).

Durante o regime de trabalho escravo no Brasil, o caráter sazonal e incerto da agricultura acabava por acentuar uma característica já inerente à escravidão: a baixa capacidade de variação do quantum de mão de obra vis a vis as variações na necessidade de trabalho exigidas pela produção. A sazonalidade e a incerteza da agricultura, portanto, vinham acentuar aquilo que Gorender chamou de "lei da rigidez da mão de obra escrava", própria do escravismo colonial (GORENDER, 1985).

Nas palavras do autor," $a$ rigidez da mão de obra escrava significa o seguinte: a quantidade de braços de um plantel permanece inalterada apesar das variações da quantidade de trabalho exigida pelas diferentes fases estacionais ou conjunturais da produção" (GORENDER, 1985: 210). Para Gorender, a rigidez da mão de obra escrava não estava relacionada apenas às conjunturas de alta e baixa solicitação de trabalho derivadas da natureza sazonal da atividade agrícola, mas também ao fato de o senhor estar atado ao escravo tanto nas conjunturas de baixa quanto nas conjunturas de alta de preços, pois a aquisição de escravos não poderia ser adaptada com versatilidade às necessidades de produção impostas pelo mercado mundial ou pelo caráter sazonal da produção agrícola.

Diferentemente, se, na economia capitalista, tem-se uma fase de alta demanda por trabalho (seja porque o ciclo de produção o exige, seja porque a conjuntura econômica é de alta de preço, requerendo o aumento da produção), a empresa contrata mais operários sem fazer qualquer adiantamento de capital-dinheiro para isso. Por outro lado, se a fase é de baixa demanda por trabalho, a empresa capitalista terá de arcar apenas com uma certa ociosidade do seu capital fixo. No caso do fa- 
zendeiro escravista, no entanto, tal possibilidade - a de adequar a quantidade de mão de obra de acordo com as necessidades de produção - não existia (GORENDER, 1985:210-211).

Essa rigidez (ou falta de flexibilidade) inerente à escravidão levava à necessidade de o quantum da produção ser decidido de acordo com a quantidade disponível de escravos que a fazenda possuísse ou pudesse adquirir. As dimensões da produção, portanto, seriam decididas de acordo com o número de braços disponíveis para a época do pico de trabalho na fazenda (época da colheita e do beneficiamento do produto):

São as dificuldades para obter a mão de obra na época da colheita e não propriamente o trato das plantações que restringiam a cultura algodoeira, pois aquele mesmo número de escravos poderia entreter maiores campos de plantio, se houvesse possibilidade de conseguir excedentes de braços durante a época da colheita (CANABRAVA, 1968:214-15).

Assim, enquanto o fazendeiro capitalista, tendo facilidade de obter mão de obra, pode dimensionar o plantio pela sua disponibilidade de capital, o fazendeiro escravista teria de estimar o cultivo pelo plantel disponível na fase de pico do trabalho agrícola, quando se conjugavam a colheita, o beneficiamento e o transporte das mercadorias. Essa rigidez ou inflexibilidade levava a, no mínimo, três consequências: 1) nos momentos intercalares da safra (momentos em que era requerida menor quantidade de trabalho, seja em ritmo, seja em número de trabalhadores), parte do plantel de escravos ficava ocioso ou, ao menos, ficava ocioso em relação ao trabalho produtivo da lavoura principal; 2) os fazendeiros tenderiam a ter na fazenda atividades com calendários de produção intercalares aos da produção principal a fim de manter o escravo produtivo nas fases estacionais ou nas fases de baixa de preço do produto principal; e 3) as inovações tecnológicas que poupassem mão de obra nas fases de menos trabalho não seriam atrativas, pois viriam apenas intensificar a disparidade entre os quanta de mão de obra, pois o pico de trabalho - a colheita - é de dificil mecanização (GORENDER, 1985: 217-222) ${ }^{2}$.

2 Além dessas, Gorender viu ainda outra consequência da rigidez da mão de obra: a sobrecarga de trabalho imposta aos escravos nos momentos de pico de trabalho nas fazendas, quando eles tinham de se submeter a extensas jornadas de trabalho. 
Caminhoá, visitando as fazendas escravistas produtoras de cana-deaçúcar e café no Rio de Janeiro e São Paulo na década de 1880, notou que, em algumas fazendas, pouco mais da metade dos escravos dedicavase a capinar e limpar o cafezal, enquanto a outra metade dedicava-se às atividades domésticas ou às atividades suplementares (CAMINHOÁ, 1880: 83). Na fazenda São Manoel, por exemplo, situada no município de Santa Maria Magdalena, no Rio de Janeiro, "o serviço da roça é[ra] feito por 115 escravos, com quanto [fosse] de 237 o seu pessoal" (CAMINHOÁ, 1880: 41).

Cardoso (1997), ao estudar as condições de produção dos charqueadores do Rio Grande, também deu atenção ao problema da sazonalidade e ao da impossibilidade da quantidade de trabalhadores ser adaptada facilmente às necessidades da produção. $\mathrm{O}$ autor notou que o charqueador gaúcho, comprando escravos, comprava força de trabalho que excedia às necessidades médias de trabalho e, por isso, a capacidade ociosa de produção de seus estabelecimentos era uma constante. As charqueadas, então, evitavam a concentração de todas as tarefas de industrialização nos meses da safra e as adiavam o mais possível para os meses seguintes. Para Cardoso, a necessidade de estender as operações do processo produtivo por todo o ano não estimulava nenhuma forma de organização mais racional do trabalho (CARDOSO, 1997: 179-180).

O sistema escravista, então, ao acarretar o problema da rigidez da mão de obra, trazia também o problema do desestímulo a inovações que poupassem trabalho, a não ser que estas viessem poupar mão de obra dos momentos de pico de demanda por trabalho, pois de nada adiantaria poupar a das fases intercalares se, nas fases de pico de trabalho, as exigências de mão de obra continuassem altas (GORENDER, 1985: 217). No caso daquelas que aumentavam a produtividade do trabalho na época do pico, como as inovações para o beneficiamento, elas foram implementadas nas décadas em que a escravidão já estava fadada a desaparecer (VIOTTI DA COSTA, 1977; STOLCKE, 1986).

Assim, a escravidão bloqueava o desenvolvimento de uma racionalidade capitalista no que dizia respeito à flexibilidade e ao uso racional do trabalho e no que dizia respeito à tendência para aumentar a composição orgânica do capital visando ao aumento da produtividade do trabalho. Portanto, para o desenvolvimento capitalista no Brasil, era necessário superar o problema da rigidez da mão de obra escrava, em 
boa medida, um problema atrelado à sazonalidade. Veremos que o uso do trabalho temporário será decisivo para isso.

Apesar da hipótese do dimensionamento da quantidade de mão de obra pelo pico de trabalho, é corrente na historiografia a ideia de que já se recorria ao trabalho temporário de escravos ou de homens livres especialmente para as tarefas mais inconstantes e para as tarefas não ligadas diretamente ao trabalho da lavoura, como para os consertos, o transporte, o trabalho industrial do açúcar, etc. (PRADO JR., 2000; BEIGUELMAN, 1971; FRANCO, 1983; DEAN, 1977; KOWARICK, 1987; VANGELISTA, 1991; entre outros).

Juntamente com a manutenção de um plantel de escravos em número maior que as necessidades médias de mão de obra, as fazendas escravistas também utilizavam de trabalho temporário, fosse do escravo alugado, fosse do trabalhador livre agregado, fosse dos sitiantes moradores próximos à fazenda ou de turmas de trabalhadores que iam de uma fazenda à outra. Todos eles eram utilizados para contornar a rigidez da mão de obra escrava nos momentos de mais trabalho.

A importância do trabalho temporário aumentou à medida que a utilização de escravos foi se tornando inviável por causa do fechamento das fontes de renovação da mão de obra escrava no Brasil (o fechamento do tráfico internacional em 1850, a libertação dos nascidos de mães escravas a partir de 1871 e o fechamento do tráfico interprovincial em 1886). Dean mostrou que, no final do século XIX, as fazendas dependiam grandemente das turmas de trabalhadores assalariados, as quais não eram empregadas para trabalho regular na plantação, sendo utilizadas somente para certas tarefas especiais, como limpar mato, construir estradas ou guiar carroças (DEAN, 1977, 35-6).

Segundo Vangelista (1991), quando a mão de obra escrava tornou-se mais dificil e mais cara, no final do século XIX, os agregados começaram a participar mais ativamente da vida da fazenda: deixou-se ao escravo o trabalho do cafezal e do artesanato, e os trabalhos mais constantes da lavoura, ao passo que o caboclo passou a desempenhar com mais frequência o papel de trabalhador temporário nas atividades colaterais ou durante a colheita (VANGELISTA, 1991:220).

Moura $(1998 ; 2007)$ mostrou que, no período de declínio do escravismo, sitiantes residentes próximos às fazendas frequentemente ajustavam contratos de trabalho temporário verbais ou escritos nas fazendas 
cafeeiras campineiras. Mostrou que esses ajustes de trabalho com mão de obra livre local eram mais frequentes do que, em geral, a historiografia costuma registrar.

Lamounier (2000) mostrou que os trabalhos da construção das estradas de ferro paulistas sofriam da escassez de trabalhadores na época de colheita do café, após a qual a oferta de trabalhadores para a construção se normalizava ou era até abundante. Dessa maneira, comprovou que os trabalhadores, já naquela época, iam e vinham de uma atividade à outra e, o que para nós é o mais importante, que eles estavam nas grandes fazendas nos momentos de pico de trabalho.

A importância de se recorrer ao trabalhador livre para contornar o problema da rigidez da mão de obra escrava, especialmente nos momentos de pico de trabalho, também foi comprovada por Messias, que mostrou que fazendas da região de São Carlos costumavam, no período de declínio do escravismo, contratar temporariamente trabalhadores nacionais livres para trabalharem ao lado dos escravos na colheita de café. Também mostrou que esse recurso não era tão esporádico, visto que esses trabalhadores eram contratados em vários anos diferentes (MESSIAS, 2003: 36-143).

Se, durante a escravidão, a hipótese é que o dimensionamento da quantidade de trabalhadores de uma fazenda era calculado pelo momento de pico de exigência de trabalho e isso acabava por limitar a área plantada, o que aconteceu após o fim da escravidão? Quais mudanças ocorreram no tocante ao dimensionamento do quantum de trabalhadores e do quantum da produção antes limitados pela rigidez da mão de obra escrava?

Se, por um lado, o problema da rigidez da mão de obra diminuiu com a possibilidade de contratar força de trabalho e não mais adquirir trabalhadores, por outro lado, uma certa rigidez ainda existia: aquela intrínseca aos trabalhos agrícolas, derivada da sazonalidade e incerteza dos trabalhos, e aquela proveniente de um mercado de trabalho ainda em formação, quando o exército de reserva necessário para propiciar elasticidade à oferta de mão de obra era ainda insuficiente.

Além do mais, dadas a sazonalidade das tarefas e a incerteza das colheitas, como manter a estratégia de estimar a quantidade de mão de obra baseando-se nos momentos de pico da demanda por trabalho? Estimar a mão de obra baseando-se nos momentos de exigência máxi- 
ma parecia ser mais viável para as culturas anuais, plantadas praticamente a cada ano, sobre as quais se tinha maior previsibilidade da safra, como a cana-de-açúcar e o algodão, afinal, "a cultura da canna tem sobre a do café, a vantagem na regularidade das colheitas" (CAMINHOÁ, 1880:14). Já para as culturas permanentes, como é o caso do café, em que a plantação era feita uma única vez e cuja colheita podia variar intensamente de ano para ano, havia menor previsibilidade da safra e, então, maior dependência da contratação de trabalhador temporário.

O aumento da necessidade de mão de obra por ocasião do plantio e, especialmente da colheita, foi contornado pelas grandes propriedades em São Paulo no pós-Abolição por uma mescla de trabalho permanente e trabalho temporário consubstanciado no arranjo colonato + trabalho temporário sazonal que, por sua vez, envolvia vários expedientes. Um deles era ocupar a mão de obra parte do tempo na produção da sua própria subsistência, como ocorria no colonato (também na parceria e no arrendamento), com o compromisso de prestação de serviços sob a forma de assalariamento temporário na atividade comercial do proprietário, segundo as conveniências do mesmo. Outro expediente era contratar a mão de obra de pequenos sitiantes da própria região ou de municípios vizinhos que migravam periodicamente em busca de trabalho. Ou, ainda, contratar o trabalho de turmas volantes que desempenhavam diversos trabalhos em diferentes fazendas. De qualquer forma, todos eles se constituíam em trabalhadores temporários sazonais nos momentos de pico de exigências de trabalho.

\section{Colonato e trabalho temporário}

[...] o mesmo problema da variação sazonal das exigências de força de trabalho existia também anteriormente na cultura do café e o colono representou uma solução admirável numa época em que o mercado de trabalho estava em gestação: presente na época da colheita como assalariado, sobrevivia com sua roça de subsistência - que preferencialmente era inclusive intercalar ao café - nos demais meses do ano (GRAZIANO, 1981:113).

Após a Abolição, nas fazendas cafeeiras passaram a vigorar, geralmente, três formas de contrato de trabalho:"a de salario, a de apanhadores e 
a de colono" (BOLETIM DO DEPARTAMENTO ESTADUAL DO TRABALHO, 1912: 20). As duas primeiras formas de contrato eram voltadas para os trabalhadores temporários contratados para tarefas específicas. A terceira forma, a de colono, referia-se a um tipo de contrato de trabalho que durava o ano todo, mas que, na prática, era uma mescla de trabalho para si, de trabalho permanente e de trabalho temporário para o fazendeiro.

O proprietário assalariava temporariamente trabalhadores para fazer frente às maiores exigências de trabalho no plantio e na colheita e procurava manter residindo na propriedade sua exigência média de braços, representada pelo número de trabalhadores necessários para os tratos culturais. Esses trabalhadores residentes responsáveis pelos tratos culturais eram contratados sob o sistema de colonato. Logo, a quantidade de colonos não era estimada pelo pico, mas pela base, isto é, pela exigência média necessária para a manutenção do cafezal que deveria ser cuidado independentemente da previsão de colheita futura.

Em 1903, época de uma crise cafeeira desencadeada pelos baixos preços do café, o fazendeiro conservava o pessoal indispensável, tentando concluir o serviço no menor prazo possível e contratando trabalhadores assalariados. A medida para contornar a rigidez da mão de obra e tornar a contratação mais flexível não era mais estender o tempo de trabalho, como acontecia na escravidão, mas dispensar o pessoal temporário nos momentos em que ele não se fazia necessário:

Actualmente o lavrador conserva o pessoal indispensável, para não deixar perecer a lavoura, e se, por acaso, tem qualquer trabalho extraordinario, é forçado recorrer ao braço assalariado. Hoje, porém, nada compensa estas despezas, por isso, elle trata de concluir o serviço no menor praso possivel e de despedir estes trabalhadores [...] (LACERDA, 1903: 26).

O sistema de colonato previa quatro tipos de remuneração de acordo com as tarefas executadas: 1) uma parcela monetária fixa paga anualmente para os tratos culturais (trato ou capina) de determinado número de pés de café; 2) um pagamento monetário variável proporcional (pago pela colheita);3) um pagamento monetário variável por dia de serviço ou por tarefa (pago por atividades extras exercidas pelo colono ou seus familiares); e 4) um pagamento não monetário, equivalente à possibilidade de o co- 
lono e sua família usufruírem dos produtos de parcela de terra da fazenda por eles cultivada com culturas alimentares.

Cada tipo de remuneração estava relacionado a um tipo de tarefa e à sua regularidade. $\mathrm{O}$ pagamento fixo se referia exclusivamente ao trabalho que era constante, assíduo, ou seja, o trato do cafezal. Já os pagamentos variáveis correspondiam às tarefas que eram mais sazonais e mais instáveis de ano para ano. E o pagamento na forma de usufruto da terra se referia aos tempos mortos do café, quando o cafezal não exigia trabalho e o colono e sua família trabalhavam nas suas próprias culturas alimentares ou no cuidado dos animais.

O pagamento monetário fixo referia-se exclusivamente ao trabalho que era permanente, isto é, que deveria ser feito algumas vezes no ano e que tinha de ser realizado independentemente do volume da colheita. Referia-se ao trabalho mais constante exigido pelo cafezal e que se distribuía ao longo do ano agrícola - a carpição ou capina, que ocorria, em geral, cinco vezes por ano.

O pagamento monetário variável proporcional referia-se ao trabalho na colheita e correspondia a uma tarefa sazonal, fosse pelo fato de ocorrer apenas uma vez ao ano, fosse pelo fato de a quantidade de trabalho em cada colheita depender da produtividade das plantas em cada ano. Era uma remuneração variável, pois era paga de acordo com o volume de café colhido medido em alqueire (medida que equivalia a 50 litros).

A remuneração por serviços extraordinários que os membros individuais da família viessem a efetuar durante o ano (não relacionados com o trato e a colheita) era baseada no dia de serviço ou na tarefa executada. A utilização extraordinária do trabalho dos colonos e de seus familiares era feita na medida das necessidades da fazenda e segundo o andamento das tarefas ordinárias (trato e colheita) correspondentes a cada família. Tais serviços abrangiam roçada de pastos, confecção ou conserto de cercas, feitura de covas, movimentação do café no terreiro, etc. $\mathrm{O}$ pagamento desses serviços não era efetuado aos indivíduos trabalhadores, mas à família, através do seu chefe, no fim do ano agrícola (SALLUM JR., 1982: 100). Esse pagamento monetário variável por dia de trabalho ou por tarefa extra realizada referia-se ao pagamento de uma tarefa esporádica, correspondente às atividades menos assíduas da fazenda cafeeira. 
O pagamento não-monetário se dava sob a forma de concessão de usufruto de terras da fazenda para o plantio do milho, feijão e, às vezes, arroz. A quantidade de terras cedidas era proporcional ao número de cafeeiros cultivados pela família do colono. A proporção e a localização das terras variavam bastante de zona para zona de produção e, mesmo, de fazenda para fazenda. As terras passíveis de serem cultivadas pelos colonos podiam estar localizadas fora do cafezal, dentro do cafezal já formado (mais de cinco anos), mas não fechado, ou dentro dos cafezais em formação (FALEIROS, 2007). Esse não pagamento feito por meio da concessão de um pedaço de terreno correspondia aos tempos mortos do café, momentos em que o café praticamente não exigia trabalho e que era resultado da diferença entre tempo de produção e o tempo de trabalho (STOLCKE, 1986; HOLLOWAY, 1984; VIOTTI DA COSTA, 1977; MARTINS, 1979; SALLUM JR., 1982). Na verdade, correspondia a um não-pagamento, visto que era feito por meio da concessão de um pedaço de terreno.

O sistema de colonato não era apenas um sistema misto de remuneração, mas era, também, um sistema misto de trabalho, combinando o trabalhador permanente e o trabalhador temporário. Além de mesclar o trabalho fixo (o trabalho do colono na capina) com o trabalho temporário do próprio colono (em tarefas extras efetuadas nos tempos mortos do cafe), o sistema de colonato mesclava o trabalho do colono com o trabalho temporário de sua família, a qual consistia num reservatório de mão de obra utilizada nos momentos de pico de trabalho nas fazendas.

Sallum Jr. (1982) questionou o porquê do movimento de reprodução do capital na produção cafeeira do Oeste Paulista implantar sistematicamente uma forma não-capitalista de exploração do trabalho. A questão central para o autor era: por que tal relação não-capitalista, a do arrendamento das terras a uma parte dos trabalhadores, que supunha capacidade excedente de trabalho das famílias contratadas não utilizada diretamente pelo capital, era necessária à reprodução do capital investido na produção de café? Mais à frente, em seu livro, o próprio autor responde:

$\mathrm{Na}$ época da colheita, acabava, portanto, a "ociosidade" existente no resto do ano agrícola. Essa "ociosidade" não era, entretanto, fruto de qualquer "irracionalidade" no modo de organizar as forças produtivas durante o processo de cultivo do café. [...] Diríamos mais: a ociosidade era produto 
necessário do capital que, no nível dos seus portadores, os fazendeiros de café, chegava a assumir a forma de "plano", de capacidade de trabalho ociosa planejada. Tratava-se de "ociosidade" produzida no cultivo para ser suprimida na colheita. Ela consistia num meio, em condições de escassez relativa de força de trabalho, que possibilitava ter-se à mão capacidade de força suplementar para a colheita (SALLUM JR., 1982: 238).

Para Stolcke e Hall o regime de colonato, ao empregar famílias em vez de trabalhadores avulsos, era importante porque representava uma reserva de mão de obra que estaria à disposição do fazendeiro, dentro de suas próprias terras, para ser utilizada nos momentos de pico de demanda de mão de obra, diminuindo a necessidade de o fazendeiro de recorrer à concorrência no incipiente mercado de trabalho (STOLCKE e HALL, 1983: 110).

Rezende apontou que o colonato, ao empregar famílias e ao permitir que seus membros mantivessem a produção de alimentos, consistia num tipo de contrato de trabalho que se adequava à peculiaridade do trabalho agrícola: a sazonalidade. Sob o regime de colonato, os membros da família que não eram necessários na época de entressafra poderiam se dedicar à cultura de alimentos e ao trato dos animais, e, na época da safra, estariam disponíveis para suprir a necessidade de aumento de mão de obra (REZENDE, 2006: 6).

Visto que os calendários agrícolas das culturas alimentares e do café eram intercalares - "O cyclo vital do milho, do arroz, do feijão e de outras plantas annuaes começa justamente quando se acaba a colheita do café e pode prolongar-se até os meses de março e abril" (BOLETIM DE AGRICULTURA, 1913: 747) - o costume de permitir que o colono e sua família plantassem alimentos dentro da fazenda representava uma maneira de lidar com a questão da exigência sazonal de mão de obra.

O sistema do colonato, ao mesclar três tipos de pagamento (fixo, variável e em espécie) e ao contratar famílias, representava uma solução engenhosa do ponto de vista da reprodução do capital porque permitia contornar vários problemas que se colocavam naquele momento derivados da sazonalidade e da incompleta formação do mercado de trabalho: permitia a redução da parcela monetária do salário (pois possibilitava a redução da parcela necessária para subsistência do trabalhador); 
permitia o pagamento exclusivo do trabalho efetuado; permitia diminuir os custos de arregimentação da mão de obra suplementar na época da colheita; e, por fim, possibilitava o ajuste automático de parte dos custos ao volume produzido a cada ano, por meio do pagamento por produção na época da colheita ou ainda por meio da flexibilidade trazida pelo cultivo de subsistência, que podia absorver mais tempo de trabalho do colono e familiares nas épocas de menores colheitas ou menores preços. Enfim, permitia driblar, em alguma medida, o problema da rigidez da mão de obra derivado das exigências sazonais de trabalho na agricultura.

\section{O trabalhador temporário sazonal}

Quando analisamos a documentação de âmbito mais geral e de cunho mais argumentativo - aquela que foi escrita para discutir a transformação do trabalho ou as questões agrícolas em geral, e que tinham, muitas vezes, fins propagandísticos (como o Boletim do Departamento Estadual do Trabalho, Boletim da Agricultura e a Revista Agrícola) -, percebemos que as referências ao trabalhador nacional ou ao trabalhador assalariado temporário eram mais negativas, justificando quase sempre a necessidade de imigração ou de medidas repressivas à vadiagem. Já quando observamos a documentação de cunho descritivo - que diz respeito ao cotidiano do mercado de trabalho, às demandas e ofertas de mão de obra, ou ao dia a dia do trabalho nas fazendas (como os anúncios publicados nos jornais e registros de fazendas) -, verificamos que os trabalhadores nacionais e o trabalhador temporário sazonal não só eram necessários em todas as fazendas durante todo o ano agrícola como sua utilização era corriqueira, necessária, aceita, e seu uso efetivo era generalizado.

$\mathrm{Na}$ transição da escravidão para o trabalho livre, já nos últimos anos do regime escravista e após a Abolição, o trabalho temporário, que antes parece ter sido apenas complementar ao trabalho escravo, foi tomando maior importância especialmente nas regiões que podiam contar com um potencial de mão de obra local, como o Oeste Velho paulista. Após a Abolição, as funções mais sazonais passaram a ser desempenhadas pelos trabalhadores temporários assalariados (que recebiam por dia, por sema- 
na, por mês ou por tarefa), enquanto as funções mais permanentes da agricultura passaram a ser desempenhadas por trabalhadores contratados sob o regime de colonato. É importante lembrar, no entanto, que mesmo o colono e sua família representavam trabalhadores temporários em uma época específica do ano agrícola, a colheita, ou quando os trabalhos do trato do cafezal o permitiam.

Segundo o Departamento Estadual do Trabalho, por volta de 1912, nas fazendas cafeeiras paulistas, além do colonato, costumavam vigorar duas outras formas de contrato de trabalho: a de salário e a de apanhadores. Essas duas formas referiam-se, geralmente, a trabalhadores não residentes (diferente, portanto, do colono) contratados para tarefas específicas e sazonais. Apesar de o Boletim do Departamento Estadual do Trabalho descrever apenas esses dois tipos de trabalho temporário (trabalhadores a salário e apanhadores), a pesquisa sobre a documentação que reflete mais concretamente o mundo do trabalho agrícola do período mostra uma realidade ainda mais complexa, envolvendo muitos outros tipos de ajustes e de ocupações.

Os trabalhadores a salário eram contratados geralmente pela própria administração da fazenda, e seus contratos podiam ser semanais, quinzenais ou mensais (diferente, novamente do colono, cujo contrato durava um ano). Por volta de 1912, aos trabalhadores assalariados pagava-se "por 10 horas de serviço de 2 a 3 mil réis, com alimentação e alojamento, ou de 3 a 4 mil réis, com alojamento mas sem alimentação" (BOLETIM DO DEPARTAMENTO ESTADUAL DO TRABALHO, 1912: 21). Todos esses trabalhadores ficavam dispostos em alojamento fornecido pelas fazendas enquanto durasse o contrato.

A bibliografia e a documentação costumam chamar o trabalhador contratado a salário como camarada. No entanto, na prática, o que se verificava era uma infinidade de designações e ocupações, o que dificulta em muito o estudo dessa categoria de trabalhador. A bibliografia mais geral, quando trata da estrutura do trabalho nas fazendas de café paulistas, costuma dividir os trabalhadores em colonos (incluindo seus familiares), camaradas e empreiteiros. Pela pesquisa em jornais de Piracicaba e Itu, verificamos que tais categorias eram realmente as mais frequentes. No entanto, em cada uma delas, à exceção dos colonos, havia uma diversidade enorme de ajustes e tipos de tarefas envolvidas que dificultam uma definição geral e exata das tarefas e tipos de "con- 
trato" a que estava sujeita cada categoria de trabalhador. Assim, o camarada podia ser também um trabalhador por turma ou um jornaleiro. Havia ainda o empreiteiro, que podia ser aquele que tinha sob suas ordens vários outros trabalhadores ou que, individualmente, se responsabilizava por entregar determinado serviço pronto numa data estipulada e que trabalhava sem nenhum trabalhador sob suas ordens, mas que havia aceitado uma tarefa por empreitada.

Mesmo na bibliografia, o termo camarada não é utilizado de maneira uniforme pelos diferentes autores. Sallum Jr., por exemplo, designa como camarada tanto os trabalhadores que "desempenhavam as mais diversas funções, ao sabor das determinações diárias da administração", aos quais chamou de "camaradas propriamente ditos - "volantes", quanto os trabalhadores mais especializados, que trabalhavam preferencialmente em tarefas mais delimitadas, aos quais chamou de "camaradas mais especializados” (SALLUM JR, 1982: 105). Bassanezi, diferentemente, não considerou todos os trabalhadores assalariados como camaradas, mas apenas alguns deles. A autora, ao analisar a estrutura ocupacional da Fazenda Santa Gertrudes, dividiu todos os trabalhadores a salário em: "camaradas"; trabalhadores em "ocupações não especializadas"; trabalhadores em "ocupações especializadas"; e trabalhadores que se "transferiam de ocupação". Além dessas, a autora notou mais de cinquenta outras diferentes designações/ocupações, tais como aprendiz de seleiro, avulso, fazedor de fubá, oleiro, pedreiro, tratador de porcos, etc. (BASSANEZI, 1973: 125).

Deixando de lado a dificuldade de agregar tais trabalhadores em uma categoria única, o importante a frisar é que sua presença era relevante tanto em termos quantitativos quanto em termos estruturais, sendo necessária para o pleno funcionamento da empresa agrícola. Os trabalhadores contratados em base salarial na Fazenda Santa Gertrudes representavam uma média de 49,5\% do total de empregados registrados nos livros conta correntes da fazenda entre 1895 e 1930. Destes, 41,5\% correspondiam a camaradas, trabalhadores com "ocupações especializadas", trabalhadores que exerciam "ocupações não especializadas" e trabalhadores que se "transferiam de ocupação" (BASSANEZI, 1973: 132).

A estimativa da representatividade desses trabalhadores no total da mão de obra empregada na fazenda, no entanto, nos dá apenas uma noção de sua importância numérica. Esses números mereceriam ser mais 
bem analisados, já que se trata de uma média para um período muito longo (1895-1930), em que as proporções de trabalhadores pode ter se alterado de um ano para outro de acordo com a conjuntura econômica, ou então, de acordo com a maior ou menor disponibilidade de mão de obra colona ou temporária sazonal. Além do mais, essa proporção podia ser maior ou menor de acordo com o momento do ano agrícola em que ela é analisada. Como sabemos, as exigências de quantidade de trabalho variavam de época para época do ano. Essa proporção, então, devia variar se a base de referência fossem os momentos de pico ou se fossem os momentos de baixa utilização de trabalhadores na fazenda. Se ponderarmos que essa estimativa baseia-se apenas nos trabalhadores registrados nos livros conta corrente da fazenda - enquanto sabemos que não eram registrados nem os familiares dos colonos, nem os trabalhadores que estavam sob às ordens dos empreiteiros - e se supusermos que os trabalhadores contratados como apanhadores na época do pico de trabalho também não apareciam registrados nos livros conta corrente da fazenda (visto que a autora não fez menção aos apanhadores), essa proporção tem de ser relativizada novamente.

A fazenda Santa Gertrudes foi uma das mais importantes fazendas de café do Estado, sendo considerada modelo: utilizava maquinários dos mais modernos para o beneficiamento, foi uma das primeiras a utilizar energia elétrica e era uma das fazendas com maior produção de café do Estado. Por isso, sua documentação é representativa da estrutura ocupacional de uma grande fazenda e nela fica comprovada a importância do trabalho temporário assalariado. Nas propriedades menores e menos colonizadas, a necessidade de contratar trabalhadores assalariados era ainda maior. Dean, comparando a documentação da fazenda Santa Gertrudes com a da fazenda Palmares, também localizada no município de Rio Claro, porém menor que a primeira, notou que a fazenda Palmares dependia grandemente das turmas fornecidas por empreiteiros independentes. Palmares também empregava muitos jornaleiros (camaradas avulsos pagos por dia de trabalho eventual, colheita e secagem dos frutos nos terreiros), em particular durante a colheita (DEAN, 1977).

Os colonos, por se manterem fixos ao longo do ano, eram mais facilmente visualizados no mundo rural e na documentação, e mais facilmente contabilizados. Geralmente contratados no início do ano agrícola, costumavam permanecer por pelo menos um ano na fazenda, 
tempo que durava o contrato de colonato. Quanto aos camaradas, cujos contratos podiam ser feitos em base mensal, semanal, quinzenal ou diária e cuja contratação se dava o ano todo, sua visualização e quantificação são mais imprecisas ou mesmo impossíveis ${ }^{3}$. De qualquer forma, em maior ou menor medida, esses trabalhadores estavam presentes em todas as plantações de café e eram indispensáveis nas diversas tarefas da fazenda cafeeira.

Além do mais, a uniformidade das tarefas desenvolvidas pelo colono torna essa categoria de trabalhadores mais fácil de ser visualizada no mundo do trabalho e mais facilmente descrita, o que facilita seu estudo enquanto grupo. Mesmo que as tarefas desenvolvidas pelos colonos fossem diversificadas, de maneira geral, elas podiam ser agrupadas em dois tipos: o trato e a colheita do café. Os assalariados, no entanto, eram contratados para uma infinidade de tarefas diferentes, por prazos diversificados e em momentos diferentes do ano. Deixando claro todas essas dificuldades envolvidas no estudo da figura dos trabalhadores assalariados, tentemos organizá-los.

\section{Assalariados e camaradas}

Os trabalhadores a salário (fossem eles chamados de camaradas, jornaleiros ou avulsos) podiam ser contratados para a realização de serviços especializados ou não. Os não especializados desempenhavam as mais diversas funções, ao sabor das determinações diárias da administração da fazenda: quebrar milho, capinar as plantações de café que não estivessem a cargo de colonos ou tipos diversos de plantações, roçar pastos, consertar caminhos, movimentar café no terreiro, cuidar dos animais da fazenda, etc. (BASSANEZI, 1973:126; SALLUM JR., 1982; VANGELISTA, 1991). Os especializados trabalhavam como podadores, aradores, maquinistas, mecânicos, ferreiros, carpinteiros, pedreiros, cocheiros, carroceiros e empregados no beneficiamento do café (BOLETIM DO DEPARTAMENTO ESTADUAL DO TRABALHO, 1912; também HOLLOWAY, 1984; VANGELISTA, 1991).

3 Bassanezi notou que, em média, 47\% das contratações dos colonos da fazenda Santa Gertrudes, entre 1895 e 1930, se deram no $4^{\circ}$ trimestre do ano (outubro a dezembro), enquanto a contratação de trabalhadores assalariados estava distribuída ao longo de todos os trimestres (BASSANEZI, 1973: 154-155). 
Todos esses trabalhadores eram contratados individualmente, diferente do colono que era contratado em unidade familiar. Podiam ser contratados diretamente pela administração da fazenda ou serem empregados indiretamente por meio de empreiteiros que tinham suas turmas de camaradas. $\mathrm{O}$ contrato ou acordo, nesse caso, era efetuado entre a fazenda e o empreiteiro, e este se responsabilizava por arregimentar os trabalhadores necessários para a execução da tarefa. O contrato do camarada era com o empreiteiro e durava o tempo da tarefa a ser realizada (ALVIM, 1986: 77).

Havia os trabalhadores assalariados que desempenhavam funções mais permanentes ao longo do ano, tais como a de transporte ou o cuidado dos animais de trabalho, e havia aqueles que desempenhavam funções mais sazonais, como varrer o café no terreiro, cortar capim, etc.

Dada a variedade de tarefas executadas pelos trabalhadores a salário, eles estavam presentes na fazenda praticamente durante o ano todo, mas suas tarefas e contratos eram intermitentes e sazonais. Eles eram importantes para a plena realização dos vários trabalhos envolvidos na empresa rural cafeeira e, em alguns casos, até mesmo para as tarefas mais assíduas, tradicionalmente deixadas a cargo do colono: "Precisa-se de uma turma de trabalhadores de roça para capinar café constituída de 15 ou 20 trabalhadores. Trata-se na rua Ipiranga, n. 5" (GAZETA DE PIRACICABA, 20 de janeiro de 1903).

Os trabalhadores assalariados podiam ser contratados entre os não residentes na fazenda ou entre os residentes, neste último caso geralmente entre os familiares dos colonos. Apesar da possibilidade de o colono e seus familiares serem contratados por dia de serviço, nenhuma fazenda estava isenta de ter de recorrer ao emprego dos trabalhadores não residentes, caso em que eram arregimentados entre a população moradora próxima às áreas de influência da fazenda, nas zonas rurais ou nas urbanas.

A pesquisa em jornais de Piracicaba e Itu mostrou que muitos fazendeiros faziam uso rotineiro dos trabalhadores temporários sazonais residentes próximos à fazenda, uma vez que abundavam anúncios para contratação de serviços em suas propriedades. Esses anúncios propunham os mais variados tipos de ocupação e de ajuste de trabalho: empreiteiros, camaradas, aradores e, especialmente, colhedores. A fazenda Vassoural, uma das mais importantes do município de Itu no início do século XX, 
procurava, em anos diferentes, trabalhadores para diversas ocupações: "Fazenda Vassoural. Nessa fazenda precisa-se de colhedores de café, como de trabalhadores de roça. Paga-se bem. Bem assim de alguns empreiteiros para fazer roçadas e picar lenhas" (A CIDADE DE YTU, 07 jun 1911).

O Boletim do Departamento Estadual do Trabalho, ao argumentar a favor da pequena propriedade como reservatório de mão de obra temporária para as fazendas, sustentava que as regiões onde havia a cultura de alimentos em pequenas propriedades não sentiam falta de mão de obra na ocasião das colheitas:

a experiência não tem desmentido essa afirmação da doutrina. As fazendas situadas nas proximidades de núcleos coloniais ou em cujas redondezas se desenvolveu a pequena propriedade (...) não lutam, pelo menos por ocasião das colheitas, com dificuldades tão grandes como as que assoberbam os proprietários de terras não favorecidos por aquelas duas condições (BOLETIM DO DEPARTAMENTO ESTADUAL DO TRABALHO, 1917(2): 276).

Moura mostrou que os pequenos sitiantes entrecruzavam os trabalhos em suas lavouras de alimentos com os trabalhos como camaradas avulsos nas fazendas e sítios médios da região de Campinas na época do declínio do escravismo. Esses ajustes de trabalho eram comuns e os fazendeiros e trabalhadores pareciam lidar com eles rotineiramente (MOURA, 1998: 64).

\section{Trabalhador por turma}

Os trabalhadores assalariados, mesmo que contratados individualmente, podiam desempenhar suas funções em turmas. Quando trabalhando coletivamente, desempenhavam as funções de acordo com as ordens de um fiscal ou feitor de turma. Esses trabalhadores também podiam ter sido arregimentados por um empreiteiro e estar, portanto, trabalhando na fazenda sob as ordens deste. Para muitos trabalhos, os fazendeiros contratavam turmas de trabalhadores constituídas por 10,20, 30 e até 40 pessoas: "Empreiteiros. Precisa-se de 30 trabalhadores para serviço de lavoura, de café e cana na fazenda do Morro Grande, distante desta cidade uma hora e meia de viagem. Paga-se muito bem. Trata- 
se na mesma com Barreto \& Cia" (GAZETA DE PIRACICABA, 21 de junho de 1895).

Havia empreiteiros que levavam suas turmas de trabalhadores de fazenda para fazenda. Essas turmas nômades permaneciam temporariamente em uma ou outra fazenda, recebendo o pagamento por dia, especialmente no período da colheita ou quando a escassez de colonos ou o abandono imprevisto da fazenda por parte destes requeria um emprego suplementar de mão de obra no cafezal:

Quando o numero de familias é insufficiente, ajustam-se turmas volantes de nacionaes em sua quasi totalidade, ás quaes, de preferencia, se confia o trabalho de movimentar o café nos terreiros mas que, em casos de necessidade aliás frequentes, são utilizadas nas carpas ou limpas dos trechos de cafezaes não colonisados, assim como no apanho das cerejas. Concluida a colheita é dispensada, em geral, toda essa gente, salvo no caso de persistir a deficiencia de colonos (RAMOS, 1923: 203, grifo meu).

Havia também as turmas nômades que realizavam trabalhos especializados, tais como a poda, o decote e a estrumação dos arbustos de café, ou a turma de matadores de formigas. A poda, por exemplo, atividade especializada importante para manter a produtividade do cafeeiro, costumava ser efetuada por turmas de podadores que migravam de uma fazenda a outra.

Outros trabalhadores por turma eram aqueles que se dedicavam às tarefas de manutenção e expansão da infraestrutura da fazenda, os quais trabalhavam nas construções, consertos, limpeza dos pastos e valados, carpição de matos à beira do cafezal, consertos das estradas, etc. A Fazenda Santa Gertrudes, por exemplo, para o dia 22 de julho de 1914, registrou, na Folha de diárias pagas, quatro pedreiros, mas estes tinham sob sua responsabilidade outras 13 pessoas trabalhando como serventes (BASSANEZI, 1973: 255).

Havia também aqueles empreiteiros que ajustavam pessoal em quantidade e com habilidade adequadas para a realização de tarefas variadas, desde podar cafeeiros até plantá-los ou então, fazer cercas de arames ou quaisquer outros serviços: "Os empreiteiros abaixo assinados encarregam-se de podar café e fazer plantação do mesmo, dispondo de pessoal muito abilitados, encarregam-se também de fazer cerca de arame e 
qualquer outro serviço concernente a sua longa practica" (GAZETA DE PIRACICABA, 28 de dezembro de 1893).

Como os trabalhadores contratados diretamente pelos empreiteiros geralmente não constavam da documentação da fazenda, visto que o contrato da fazenda era com o empreiteiro, os ajustes entre estes e os trabalhadores da turma dificilmente podem ser reconstruídos pela documentação das fazendas. Para o dia 23 de julho de 1914, por exemplo, a Fazenda Santa Gertrudes registrava contrato com nove empreiteiros, no entanto não apresentava o número de trabalhadores que estavam sob as ordens deles (BASSANEZI, 1973: 255).

Assim como os trabalhadores individuais contratados diretamente pela administração da fazenda, os empreiteiros e os trabalhadores por turma eram contratados na região de influência da propriedade e também em regiões circunvizinhas mais distantes. As empreitadas para derrubar e formar cafezal, bem como as empreitadas para podar os pés de café, comumente requeriam trabalhadores de outros municípios. No jornal Gazeta de Piracicaba foram encontrados anúncios procurando por empreiteiros para formar cafezal nos municípios de Batatais, Botucatu, Brotas, São Carlos do Pinhal, São Pedro, Capivari, São Manuel do Paraíso e Charqueada:

Derrubada. Precisa-se de empreiteiros para roçar e derrubar de 25 a 30 alqueires de mata no município de São Carlos do Pinhal.A mata é boa tanto para roçar como para derrubar, e fica retirada da fazenda apenas 200 braças; dá-se casa para morada, e além da roçada, tem muito serviço na fazenda. Paga-se bem. (GAZETA DE PIRACICABA, 27 mar 1892).

Outro trabalho geralmente entregue a empreiteiros com suas turmas de trabalhadores era o de construção de toda a estrutura necessária para a formação de uma fazenda, como as moradias dos colonos, os terreiros, as tulhas, o paiol, etc. Além dos camaradas que realizavam os serviços não especializados da construção, essas turmas de trabalhadores assalariados era composta de trabalhadores mais especializados, como pedreiros, carpinteiros e marceneiros: "Valleiros: na Fazenda Água Santa, distante 2 léguas desta cidade, preciza-se de uma turma de valeiros para retocar vallos. Para tratar na mesma fazenda, com o administrador sr. Domingos da Rocha Meira. Paga-se bem." (GAZETA DE PIRACICABA, 24 de novembro de 1892). 


\section{Apanhadores de café}

Outro tipo de contrato vigente nas fazendas cafeeiras, segundo o Boletim do Departamento Estadual do Trabalho, era o de apanhadores, cujo contrato durava o tempo da colheita:

No contrato de apanhadores de café, que dura o tempo da colheita (tres a quatro meses), obriga-se o fazendeiro a fornecer gratuitamente ao apanhador transporte da estação próxima á fazenda e desta àquela depois de terminada a colheita, casa de moradia e pagamento semanal, quinzenal ou mensal. [...]... por 50 litros de café colhido, limpo, ensacado e entregue nos carreadores, para a respectiva medição (BOLETIM DO DEPARTAMENTO ESTADUAL DO TRABALHO, 1912: 21)

Os contratados não poderiam abandonar a fazenda antes de terminar a colheita. Se o fizessem, perderiam um terço do que tivessem ganhado e não teriam direito aos meios de transporte da fazenda à estação mais próxima (BOLETIM DO DEPARTAMENTO ESTADUAL DO TRABALHO, 1912: 25) Após a colheita, esses trabalhadores eram, em geral, dispensados. Eram pagos por volume colhido, assim como os colonos e seus familiares, e também eram contratados, preferencialmente, em núcleos familiares, chamados famílias de apanhadores. Na época de demanda intensa de trabalho, quando as famílias não eram suficientes, as fazendas também contratavam os apanhadores avulsos, denominados solteiros. Estes podiam ser contratados individualmente, porém era mais comum serem contratados em turmas sob a responsabilidade de um empreiteiro:

Quando o fazendeiro não dispõe de colonos sufficientes, engaja turmas de pessoal para apanha. Essas turmas, a que habitualmente se dá o nome de turmas de solteiros são pagas a jornal e retiram-se findo o serviço. Quase todo esse pessoal reside em outros Estados de onde vem em auxilio das fazendas, tal como na França e na Argentina onde para o trabalho das colheitas chegam trabalhadores italianos temporariamente engajados (RAMOS, 1923: 120).

As turmas de apanhadores eram compostas de migrantes nacionais ou de trabalhadores requisitados no município onde a fazenda estava localizada:"Colhedores. Precisa-se de uma turma de 15 a 20 pessoas para 
colher café. Paga-se bem. Para tratar com o major José da Cruz Moraes Sampaio" (GAZETA DE PIRACICABA, 19 jun 1909).

Vangelista (1991), ao analisar as demandas por trabalhadores e as contratações registradas na Agência Official de Collocação (agência criada em 1906 pelo governo do Estado de São Paulo para facilitar a colocação de trabalhadores na lavoura e indústria), mostrou que havia alta correlação entre o aumento na demanda por apanhadores e o aumento na exportação de café (e, portanto, na produção). No caso de colonos, contrariamente, a autora não notou essa correlação (VANGELISTA, 1991: 92-94). A explicação para essa correlação é óbvia: como o número de pés de café de uma fazenda não variava de ano para ano, mas a colheita, sim, anos de maiores colheitas significavam mais trabalho somente no momento de pico, mas não mais trabalho regular. Ou seja, independentemente do volume colhido, o número de pés de café a ser cuidado era o mesmo, exigindo, portanto, o mesmo número de colonos (visto que o número de colonos era calculado de acordo com o número de pés de café da fazenda e não de acordo com a previsão de produção). A colheita, por sua vez, podia exigir maior ou menor contratação de colhedores e outros trabalhadores temporários para as diferentes tarefas executadas naquela fase do ano agrícola, mas não exigiam a contratação de mais colonos. Daí a correlação existente entre maior produção e maior demanda por apanhadores.

A pesquisa nos anúncios dos jornais mostrou que era grande a procura por colhedores de café (e, em Itu, também por colhedores de algodão e, em Piracicaba, por cortadores de cana-de-açúcar) nos anos de maior produção, já prenunciando o que se tornaria padrão na agricultura brasileira paulista: a contratação sazonal de trabalhadores temporários sem vínculos com a propriedade para colherem algodão e café ou para cortarem cana-de-açúcar.

Assim comoVangelista notou uma alta correlação entre demanda por apanhadores e exportação de café, nas pesquisas sobre os jornais pudemos perceber a mesma relação. Se a demanda por apanhadores publicada nos jornais era bastante corriqueira (como pudemos perceber para uma série de cerca de 30 anos) $)^{4}$, ela era bastante diferente em termos quantitativos

4 Série de 31 anos para o jornal Gazeta de Piracicaba (de 1889 a 1920) e série de 22 anos para o jornal $A$ Cidade de Ytú (1893 a 1915). 
de ano para ano e variava de acordo com a maior ou menor colheita no município. Nos anos em que encontramos pouca procura por trabalhadores, encontramos dados de baixa produção no município. Contrariamente, nos anos de alta procura, encontramos notícias de colheitas abundantes.

Além disso, nos anos em que tais trabalhadores eram mais requisitados, o eram em grande quantidade, visto que o aumento ou a diminuição da produção ocorreria para praticamente todas as propriedades da região ao mesmo tempo. Como as fazendas de uma mesma região eram acometidas pelas mesmas condições de clima e temperatura (tais como geadas, frio intenso, secas prolongadas ou chuvas muito fortes) e estas eram determinantes da colheita, quando a demanda por trabalho aumentava numa fazenda, aumentava para todas da região.

Portanto, percebe-se que, se excluindo os colonos e alguns outros trabalhadores que executavam os trabalhos mais permanentes, o restante da mão de obra das fazendas era constituído por trabalhadores contratados temporariamente. Estes trabalhadores temporários podiam ser familiares dos colonos contratados a salário para trabalhos esporádicos ou como apanhadores na época da colheita. Podiam ser também trabalhadores não residentes que mantinham diversos tipos de vínculos com a fazenda: assalariados não especializados contratados na época da colheita; trabalhadores assalariados especializados contratados em qualquer época do ano, trabalhadores contratados pela administração da fazenda ou por meio de empreiteiros; famílias de apanhadores ou turmas de solteiros contratadas para as colheitas.

\section{Considerações finais}

Quando a nossa lavoura não precisar ter nas fazendas mais do que o pessoal de custeio ordinário e poder recorrer na época da colheita a um pessoal externo às fazendas [...] o lavrador ver-se-á mais desembaraçado de despesas e poderá encurtar a duração da epocha da colheita, o que será de superior vantagem [...]. (BOLETIM DA AGRICULTURA, 1901 (9): 590).

A dependência do trabalho agrícola em relação aos ciclos e incertezas naturais gerava uma demanda incerta e sazonal por trabalho. Assim, 
o trabalhador temporário era parte importante e necessária na estruturação da atividade econômica da época, pois se adaptava à demanda incerta e sazonal. O arranjo colonato + trabalho temporário sazonal foi um sistema de trabalho específico, surgido para dar conta da transição entre a escravidão e o trabalho livre, e para dar conta da transição entre a predominância do trabalho fixo e residente e a predominância do trabalho temporário não residente (volante) na agricultura paulista.

Ao mesclar trabalho fixo com trabalho temporário sazonal (o primeiro representado pelo colono e o segundo pelos familiares do colono, pelas turmas de solteiros, pelas famílias de apanhadores ou pelos assalariados em geral), tal sistema foi uma solução engenhosa que trazia vantagens para o capital quando comparado com o regime de trabalho escravo, pois permitia o aumento da rentabilidade das unidades produtivas, desonerando o fazendeiro do pagamento da mão de obra nos momentos de não-trabalho na produção comercial e permitindo, além do mais, o rebaixamento do preço da mão de obra, tanto do trabalhador fixo, quanto do trabalhador temporário.

Ao verificarmos que a um aumento da colheita correspondia um aumento da utilização de trabalhadores temporários sazonais, especialmente os colhedores, verificamos que o trabalho temporário sazonal era importante para permitir a flexibilização dos custos de produção de acordo com o volume produzido.A disponibilidade desses trabalhadores, portanto, era necessária e crucial.

O contrato de colonato, ao reter o trabalhador dentro da fazenda, protegia o fazendeiro, somente até certo ponto, dos problemas provenientes da sazonalidade das exigências de trabalho e da incerteza quanto ao volume da colheita. Ao reter o trabalhador e seus familiares até o final do ano agrícola, o contrato de colonato garantia que parte do exército de reserva de mão de obra necessário para a colheita estivesse dentro da fazenda, atrelada a ela por contrato, mas não garantia que ele fosse suficiente para dar cabo de todo o trabalho nos anos de maior demanda. Por mais que o colonato lhe desse flexibilidade, o número de colonos contratado tinha de ser calculado pelo número de pés de café que tinham de ser cuidados e não pelo número estimado de trabalhadores para a colheita.

Durante a escravidão, o fazendeiro tinha de dimensionar a quantidade de mão de obra necessária para a produção pelo momento de pico 
de trabalho. No arranjo colonato + trabalho temporário sazonal, de maneira diferente, a quantidade de mão de obra era dimensionada pelo número de trabalhadores necessários para o trato dos cafezais. Estimar a quantidade de trabalho pelo nível necessário para o trato (e não pelo pico) e complementar com o trabalho temporário sazonal permitia ao fazendeiro o uso mais racional do fator de produção trabalho, flexibilizando seu custo em relação ao volume produzido, permitindo contornar os problemas derivados da sazonalidade, da inconstância da produção e da oscilação de fases de alta e baixa nos preços do café.

Logo, o trabalho temporário associado ao colonato era condição para a modernização, pois permitia maior racionalidade na gestão, na medida em que permitia essa composição maior entre colono (trabalhador fixo) e trabalhador sazonal. Caso houvesse facilidade de obtenção de trabalhadores assalariados temporários, a empresa cafeeira poderia até mesmo reduzir o número de colonos. Quanto maior a possibilidade de emprego dos trabalhadores temporários sazonais, maior a flexibilidade.

Se o emprego do trabalho temporário sazonal contribuía favoravelmente para a empresa rural cafeeira, no entanto, inverter a relação trabalho permanente/trabalho temporário a tornaria vulnerável à escassez de trabalhadores durante os meses críticos da colheita, uma vulnerabilidade que a fazenda conseguia driblar apenas em parte com o sistema de colonato. De qualquer forma, a solução para a flexibilização total dos custos com mão de obra que foi colocada em prática somente na segunda metade do século XX já estava dada e já era reconhecida como tal: o trabalho temporário levado ao extremo com os moradores (ou trabalhadores residentes) sendo expulsos das fazendas e trocados pelas turmas de volantes:

[o fazendeiro] tendo facilidade de obter o suprimento extraordinário de braços, na ocasião da colheita, reduziria bastante as suas despesas de custeio, dispensando um bom número de pessoal permanente, que agora se vê obrigado a sustentar, para garantia do trabalho regular da fazenda (Relatório da Secretaria dos Negocios da Agricultura, Commercio e Obras Publicas do Estado de São Paulo, 1907, grifo do autor)

A solução é que o trabalho temporário passasse a ser o predominante, enquanto o permanente (o trabalho do colono) passasse a ser mino- 
ria. Se a solução ainda não era colocada em prática da forma sob a qual um dia o seria, era por uma questão fundamental: a falta de mão de obra abundante e barata. "O ponto melindroso do problema a resolver hoje, parece-nos, já o dissemos, é o da mão de obra abundante e barata para o nosso trabalho agrícola" (TELLES, 1901: 3). Só o exército de reserva plenamente formado permitiria uma oferta elástica de mão de obra, necessária para atividades com demanda sazonal por trabalho. Só assim a fazenda poderia contornar os problemas implicados na manutenção dentro de sua propriedade daquela parcela de "bocas inúteis, a fim de conservar braços para a colheita" (VERT, 1903: 74).

\section{Documentos}

A Cidade de Ytú. Itu, SP: 1893 a 1915.

SOBRINHO, Julio Brandão (org). Almanach Illustrado do Lavrador Paulista organizado por Julio Brandão Sobrinho, inspector do 10 districto Agronomico. São Paulo: Duprat \& Comp. 1906.

Calendario Agricola de S.V.Vigneron Jousselandiére. In: LOPES, Antonio de Castro. Catechismo de agricultura para uso das Escolas de Instrução primaria do Brasil por Antonio de Castro Lopes. Rio de Janeiro: Typographia Americana, 1869.

CAMARGO, João Ayres de. As estradas de rodagem do Estado de São Paulo; artigos publicados no Jornal do Commercio de São Paulo. São Paulo:Typographia Brasil de Rothschild \& Co., 1923.

CAMINHOÁ, Luiz Monteiro. Cana de assucar e café. Relatório apresentado ao Governo Imperial pelo engenheiro Luiz Monteiro Caminhoá. Rio de Janeiro:Typographia Nacional, 1880.

Condições do trabalho na lavoura cafeeira do Estado de S. Paulo. Secretaria da Agricultura, Commercio e Obras Publicas do Estado de São Paulo. Boletim do Departamento Estadual do Trabalho, São Paulo, n.1-2, 4º trim. 1911 - 1º trim., 1912.

DAVATZ, Thomas. Memórias de um colono no Brasil:1850. Belo Horizonte: Ed. Itatiaia; São Paulo: Ed. da Universidade de São Paulo, 1980.

DENIS, Pierre. Brazil 1911. London:T. Fisher Unwin Ltd., 1911.

DUARTE, Carlos. Considerações sobre a cultura mechanica do cafeeiro. Secretaria da Agricultura, Commercio e Obras Publicas do Estado de São Paulo. Boletim da Agricultura. Anno de 1913. São Paulo, 14ª serie, n. 5, mai. 1913.

Emigração inter-regional para as colheitas. Secretaria da Agricultura, Commercio e Obras publicas do Estado de São Paulo. Boletim do Departamento Estadual do Trabalho, São Paulo, ano 7, n. 23, $2^{\circ}$ trim. 1917.

Gazeta de Piracicaba. Piracicaba, SP: 1882-1920. 
LACERDA, Candido F. Estudo da Meiação, Parceria, etc. e das suas vantagens. Propaganda para os lavradores e colonos por Candido F. de Lacerda. São Paulo:Typographia Brazil de Carlos Gerke, 1903.

Oficio da Superintendencia de Obras Publicas do Estado de São Paulo, 22 abr. 1890.

RAMOS, Augusto. O café no Brasil e no estrangeiro. Rio de Janeiro: Pap. Santa Helena, 1923.

REPARTICAÇÃO de Estatistica e do Archivo de São Paulo. Annuario estatistico de São Paulo (Brasil) 1905: estatistica economica e moral. São Paulo:Typ. Espindola \& Comp., v. 2, T. 2, 1907.

SECRETARIA da Agricultura, Commercio e Obras Publicas do Estado de São Paulo. Boletim de Agricultura.Anno de 1900. São Paulo:Typographia do Diario Official, 1901, n.6 (suplemento)

Secretaria da Agricultura, Commercio e Obras Publicas do Estado de São Paulo. Boletim da Agricultura. Anno de 1905. São Paulo: Red. da Revista Agricola,VI, n. 1, jan. 1906.

Secretaria da Agricultura, Commercio e Obras Publicas do Estado de São Paulo. Boletim da Agricultura. Anno de 1913. São Paulo: Red. Da Revista Agricola, XIV, n. 11-12, nov/dez. 1913.

Secretaria dos Negocios da Agricultura, Commercio e Obras Publicas do Estado de São Paulo. Relatorio apresentado ao Dr. Jorge Tibiriçá, presidente do Estado pelo Dr. Carlos Botelho, secretário da Agricultura. Anno de 1905. São Paulo:Typographia Brazil de Rothschild \& Co, 1906.

TELlES, Augusto C. Silva. A producção brazileira. Revista Agrícola. Orgam da Lavoura, Industria e Commercio. São Paulo: 15 jan 1901, n. 66, p. 1-7.

VERT, Germano. Ainda a crise do café. Revista Agricola. São Paulo: anoVIII, 15 fev. 1903, n. 91.

\section{Referências bibliográficas}

ALVIM, Zuleika M. F. Brava gente! Os italianos em São Paulo. 1870-1920. São Paulo: Brasiliense, 1986.

BASSANEZI, Maria Silvia C. Beozzo. Fazenda de Santa Gertrudes. Uma abordagem quantitativa das relações de trabalho em uma propriedade rural paulista (1895-1930). Rio Claro, SP: [s.n.], 1973 (tese doutorado - Universidade Estadual Paulista, Faculdade de Filosofia, Ciências e Letras).

BASTIDE, Roger; FERNANDES, Florestan. Brancos e negros em São Paulo. São Paulo: Ed. Nacional, 1959.

BRANT,Vinícius Caldeira. Do colono ao bóia-fria: transformações na agricultura e constituição do mercado de trabalho na Alta Sorocabana de Assis. Estudos Cebrap, São Paulo, n. 19, p. 37-92, 1977.

CANABRAVA, Alice Piffer. A grande propriedade rural In: HOLANDA, Sérgio Buarque (org.) História Geral da Civilização Brasileira. A Época colonial: administração, Economia, Sociedade. São Paulo: Difusão Européia do Livro, 1968 (tomo I, volume 2). 
CANABRAVA, Alice P.; MENDES, Maria Tereza. A região de Piracicaba. Revista do Arquivo Municipal, São Paulo, vol. XLV, 1938.

CARDOSO, Fernando Henrique. Capitalismo e escravidão no Brasil Meridional. O negro na sociedade escravocrata do Rio Grande do Sul. São Paulo: Paz e Terra, 1997.

COSTA, Wilma Peres. A questão fiscal na transformação republicana - continuidade e descontinuidade. Economia e Sociedade. Campinas, vol. 10, p. 141-173, jun. 1998.

DEAN, Warren. Rio Claro: um sistema brasileiro de grande lavoura, 1820-1920. Rio de Janeiro: Paz e Terra, 1977.

FALEIROS, Rogério Naques. Fronteiras do Café: fazendeiros e "colonos" no interior paulista (1917-1937). Campinas, SP: [s.n.], 2007. (Tese doutorado - Universidade Estadual de Campinas, Instituto de Economia).

FRANCO, Maria Sylvia. Homens Livres na Ordem Escravocrata. São Paulo: Kairós Livraria Editora, 1983.

GRAZIANO da Silva, José. Progresso Técnico e Relações de Trabalho na Agricultura. São Paulo: Hucitec, 1981 (coleção Economia e Planejamento).

GONZALES, Élbio N.; BASTOS, Maria Inês. O trabalho volante na agricultura brasileira. In: Departamento de Economia Rural da Faculdade de Ciências Agronômicas da Unesp (org). A mão de obra volante na agricultura. São Paulo: CNPq/UNESP/ Polis, 1982.

GORENDER, Jacob. O escravismo colonial. São Paulo: Ática, 1985.

HOLLOWAY, Thomas H. Imigrantes para o café: café e sociedade em São Paulo, 1886-1934. Rio de Janeiro: Paz e Terra, 1984.

KOWARICK, Lúcio. Trabalho e vadiagem - A origem do trabalho livre no Brasil. São Paulo: Brasiliense, 1987.

LAMOUNIER, Maria Lúcia. Ferrovias, agricultura de exportação e mão-de-obra no Brasil no século XIX. História Econômica \& História de Empresas, São Paulo, v. 3, n. 1, p. 43-76, 2000.

LANNA,Ana Lúcia Duarte. A transformação do trabalho: a passagem para o trabalho livre na Zona da Mata Mineira, 1870-1920. Campinas: Editora da Unicamp; Brasília: CNPq, 1988.

MELLO, Maria Conceição D’Incao. O "Bóia-Fria”: acumulação e miséria. Petrópolis, Rio de Janeiro:Vozes, 1976.

MESSIAS, Rosane Carvalho. O cultivo do café nas bocas de sertão paulista. Mercado interno e mão-de-obra no período de transição: 1830-1888. São Paulo: Ed. da Unesp, 2003.

MILLIET, Sérgio. Roteiro do Café e outros ensaios. Contribuição para o estudo da História Econômica e Social do Brasil. São Paulo: Hucitec/Instituto Nacional do Livro Fundação Nacional Pró-Memória, 1982.

MONBEIG, Pierre. Pioneiros e fazendeiros de São Paulo. São Paulo: Hucitec/Polis, 1984.

MOURA, Denise A. Soares de. Saindo das Sombras: homens livres no declínio do escravismo. Campinas: Área de publicações CMU/Unicamp, 1998.

Soares de. Cafeicultores e lavradores de roças de alimentos na transição do trabalho escravo ao livre (Campinas, 1850-1888). América Latina en la Historia Económica, México, v. 27, p. 79-110, jan/jun 2007. 
NAXARA, Márcia Regina Capelari. Estrangeiro em sua própria terra: representações do brasileiro, 1870/1920. São Paulo: Annablume, 1998.

PRADO JR., Caio. Formação do Brasil Contemporâneo: colônia. São Paulo: Brasiliense/ Publifolha, 2000.

RAMOS, Pedro. História econômica de Piracicaba (1765-1930): as particularidades do complexo canavieiro paulista. In:TERCI, Eliana T. (org.). O desenvolvimento de Piracicaba: história e perspectivas. Piracicaba/SP: Editora da Unimep, 2001.

REZENDE, Gervásio Castro de. Políticas trabalhista, fundiária e de crédito agrícola no Brasil: uma avaliação crítica. Revista de Economia e Sociologia Rural, Rio de Janeiro, v. 44, n. 1, p. 47-78, jan/mar 2006.

SANTOS, Carlos José Ferreira dos. Nem tudo era italiano. São Paulo e pobreza: 1890-1915. São Paulo:Annablume/Fapesp, 2003.

SALLES, Iraci Galvão. República: a civilização dos excluídos (representações do trabalhador nacional. 1870-1920). São Paulo: tese de doutoramento apresentada ao Departamento de História/FFLCH, USP, 1995.

SALLUM JR., Brasilio. Capitalismo e Cafeicultura: oeste paulista, 1888-1930. São Paulo: Duas Cidades, 1982.

SCOTT, Rebecca J. Emancipação escrava em Cuba: a transição para o trabalho livre, 1860-1899. Rio de Janeiro: Paz e Terra; Campinas, SP: Editora da Unicamp, 1991.

STOLCKE, Verena; HALL, Michael. A introduçao do trabalho livre nas fazendas de café de São Paulo. Revista Brasileira de História, São Paulo, v. 3, n. 6, p. 80-120, set. 1983.

STOLCKE,Verena. Cafeicultura. Homens, Mulheres e Capital (1850-1980). São Paulo: Brasiliense, 1986.

TESSARI, Cláudia Alessandra. Braços para colheita: sazonalidade e permanência no trabalho temporário na agricultura paulista (1890-1915). Campinas, SP: [s.n.], 2010.(Tese doutorado - Universidade Estadual de Campinas, Instituto de Economia).

VANGELISTA, Chiara. Os Braços da Lavoura. Imigrantes e "Caipiras" na Formação do Mercado de Trabalho Paulista (1850-1930). São Paulo: Hucitec, Instituto Italiano di Cultura, Instituto Cultural Ítalo-Brasileiro, 1991.

VIOTTI DA COSTA, Emília. Da Monarquia à República: momentos decisivos. São Paulo: Grijalbo, 1977. 


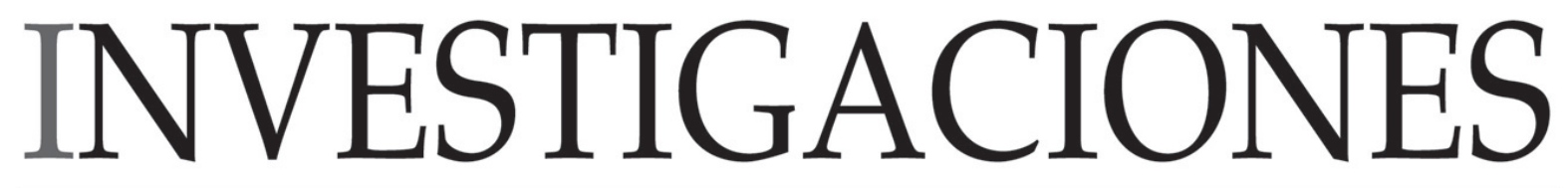

VOLUMEN 8 • NÚMERO 1 • FEBRERO 2012

\section{de HISTORIA ECONÓMICA}

\section{in memoriam}

PEDRO SCHWARTZ GIRÓN

Manuel Jesús González González (1941-2011)

\section{artículos}

ROCÍO SÁNCHEZ LISSEN Y MARÍA TERESA

SANZ DÍAZ

La difusión en España de la obra de Milton Friedman y su influencia en la política económica española (1956-1977)

FLORENT LE BOT Y CÉDRIC PERRIN

El Estado y la industria del calzado en Francia en el siglo XX. La definición de una escala territorial para la coordinación entre los poderes públicos y las empresas

FRANCISCO J. GOERLICH GISBERT

Datos climáticos históricos para las regiones

españolas. CRU TS 2.1

SALVADOR CALATAYUD

El Estado en los campos. La regulación del cultivo del arroz en la España del siglo XIX

\section{reseñas}
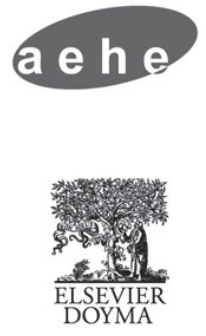


\section{normas para publicação}

(recomendações para os autores)

Os trabalhos a serem submetidos para publicação devem ser remetidos por e-mail, ou em via impressa com CD/DVD, gravado em programa Word for Windows 7 (ou versão mais atual). Devem conter resumos (de no máximo 10 linhas) em português e inglês, com 5 palavraschave nestes dois idiomas.

Os trabalhos devem seguir as seguintes especificações: fonte: Times New Roman, corpo 12 entrelinha $1 \frac{1}{2}$, as tabelas montadas no Word. Nos gráficos e tabelas utilizar fonte Arial, corpo 7. Os gráficos, quadros, desenhos, mapas e imagens não devem ultrapassar a largura de $11,5 \mathrm{~cm}$, podem ser enviados nas extensões: CDR, EPS, JPG ou TIF, em tons de cinza com resolução de 300 DPI. Toda imagem deve ser enviada em arquivo separado do texto acompanhada de cópia impressa.

As citações apresentadas no texto devem seguir normas da ABNT NBR 10520:

\section{Citação direta com menos de 3 linhas}

Segundo Furtado, a desvalorização cambial estimulou a atividade industrial interna [...] "foi sobre a base desse novo nível de preços relativos que se processou o desenvolvimento industrial dos anos trinta" (FURTADO, 1974: 204).

Citação com mais de 3 linhas: deve ser retirado do texto, com recuo de $4 \mathrm{~cm}$ na margem esquerda, fonte menor (11), espaçamento simples, sem aspas.

Encarada sob esta perspectiva, isto é, à luz dos objetos mercantis que impulsionaram a expansão ultramarina, compreende-se por que, durante mais de um quarto de século, a descoberta do Brasil tenha permanecido um episódio de importância secundária para os portugueses. (CANABRAVA, 2005: 41)

Citação indireta: a menção dos autores deve ser apresentada da mesma forma utilizada para as citações diretas. Não há necessidade de indicar número de página da fonte no caso de paráfrase.

A referência completa deve ser relacionada no final do trabalho, em ordem alfabética, segundo normas da ABNT NBR 6023.

Exemplos:

\section{Referência de livro}

FURTADO, Celso. Formação Econômica do Brasil. 12 ed. rev., São Paulo: Companhia Editora Nacional, 1974.

Se o autor tiver mais de um trabalho referido, deve-se relacioná-los em ordem cronológica, começando pelos mais antigos.

\section{Referência de capítulo de livro}

PRADO JÚNIOR, Caio. O sentido da colonização. In: . Formação do Brasil

Contemporâneo. São Paulo: Brasiliense; Publifolha, 2000, p.17-21.

\section{Referência de artigo de revista}

LEVY, Maria-Bárbara e SAES, Flávio A. Marques de. Dívida externa brasileira, 1850-1913: empréstimos públicos e privados. História Econômica \& História de Empresas, São Paulo, v. 4, n.1, p. 49-81, 2001. 


\section{Referência de documento eletrônico}

BRASIL. MINISTÉRIO DO PLANEJAMENTO, ORÇAMENTO E GESTÃO. IBGE Estatística do século XX. Rio de Janeiro, 19 abr. 2007. Disponível em: <http://www.ibge.gov.br>. Acesso em: 19 abr. 2007.

\section{Referência de eventos}

CANABRAVA, Alice Piffer. Um capítulo da história das técnicas no Brasil: o emprego do bagaço de cana como combustível dos engenhos. In: CONGRESSO DE HISTÓRIA NACIONAL. 4, 1949, Rio de Janeiro, Anais... Rio de Janeiro: Imprensa Nacional, 1952.

Os trabalhos submetidos poderão ser apresentados em português, inglês, francês e espanhol, observando-se a necessidade de apresentação de resumos em português e inglês.

A submissão do trabalho implica sua autorização para publicação na revista. Não serão pagos direitos autorais.

\section{O material deve ser remetido para}

Teresa Cristina de Novaes Marques

Departamento de História/UNB

ICC Norte, $1^{\circ}$ andar

CEP 70910-900

Brasília, DF

Email: tcnmarques@uol.com.br

Telefone: 0XX 61 3107-6632 


\section{SÓCIOS HONORÁRIOS}

Alice Piffer Canabrava in memoriam

Annibal Villanova Villela in memoriam

Celso Furtado in memoriam

Charles R. Boxer in memoriam

Eulália Maria Lahmeyer Lobo †

Frédéric Mauro in memoriam

Jacob Gorender

Manoel Correia de Andrade in memoriam

Nelson Werneck Sodré in memoriam

Roberto Cortés Conde

\section{SÓCIOS FUNDADORES} E EFETIVOS

\section{REGIÃO CENTRO-OESTE}

Barsanufo Gomides Borges

Carmen Lícia Palazzo de Almeida

Domingos Savio da Cunha Garcia

Dulce Portilho Maciel

Edison Antônio de Souza

Einstein Almeida Ferreira Paniago

Fernando Tadeu de Miranda Borges

Flávio Rabelo Versiani

Guilherme Costa Delgado

Hamilton Afonso de Oliveira

Jocimar Lomba Albanez

José Manuel Carvalho Marta

Julio Cesar Bentivoglio

Lúcio Ismael de Alvarenga

Luís Sérgio de Oliveira Araújo

Maria Teresa Andrade Ribeiro de Oliveira

Maurício Otávio de Mendonça Jorge

Nanci Leonzo
Otávio Canavarros

Paulo Roberto Cimó Queiroz

Paulo Roberto de Almeida

Ricardo Bielschowsky

Stephen Anthony de Castro

Teresa Cristina Novaes Marques

\section{REGIÃO SUDESTE}

Adriano Braga Teixeira

Afonso de Alencastro Graça Filho

Alexandre de Sá Avelar

Alexandre Mendes Cunha

Alexandre Queiroz Guimarães

Almir Chaiban El Kareh

Ana Claudia Caputo

Ana Lucia Nunes Penha

Ana Maria Kirschner

Anderson José Pires

André Arruda Villela

Angelo Alves Carrara

Antônio Eugênio da Costa Almeida

Antonio Maria da Silveira

Araken Alves de Lima

Bernardo Kocher

Carlos Alberto Campello Ribeiro

Carlos Alberto Medeiros Lima

Carlos Augusto Vidotto

Carlos Eduardo Suprinyak

Carlos Gabriel Guimarães

Carolina Miranda Cavalcante

Claudia Maria das Graças Chaves

Clélio Campolina Diniz

Daniel do Val Cosentino

Dilma Andrade de Paula

Ebenezér Pereira Couto

Edson Alvisi Neves

Eduardo da Motta e Albuquerque

Eduardo Nazareth Paiva

Elione Silva Guimarães

Elisa Maria de Oliveira Müller

Elisabeth von der Weid

Eulália Maria Lahmeyer Lobo †

Fábio Campos Barcelos
Fabio de Silos Sá Earp

Fabio Ferreira Ribeiro

Fania Fridman

Felinto Pessoa de Faria Neto

Fernando Antonio Abrahão

Fernando Carlos Greenhalgh de Cerqueira Lima

Fernando da Matta Machado

Fernando Gaudereto Lamas

Frederico Gonzaga Jayme Junior

Geraldo de Beauclair Mendes Oliveira

Heitor Pinto de Moura Filho

Heloisa Helena Pacheco Cardoso

Hildete Pereira de Melo Hermes de Araújo

Hugo Eduardo Araujo da Gama Cerqueira

Irene Nogueira de Rezende

Ismênia de Lima Martins

Ivan da Costa Marques

Ivanil Nunes

Jaques Kerstenetzky

João Antonio de Paula

Jorge Enrique Mendoza Posada

José Newton Coelho Menezes

Luciana Lambert Pereira

Luís Frederico Barreto Rodrigues

Luis Otávio Pano Tasso

Luiz Antonio Silva Araújo

Luiz Carlos Soares

Luiz Cláudio Moisés Ribeiro

Luiz Fernando Saraiva

Marcelo Magalhães Godoy

Maria Antonieta Parahyba Leopoldi

Maria Celina Soares D'Araújo

María Verónica Secreto

Maria Yedda Leite Linhares †

Mario Marcos Sampaio Rodarte

Mônica de Souza Nunes Martins

Nelson Nozoe

Newton Augusto Cardoso de Oliveira

Newton Paulo Bueno

Nicélio do Amaral Barros 
Norberto Osvaldo Ferreras

Paulo Coelho Mesquita Santos

Pedro Henrique Pedreira Campos

Pedro Puntoni

Rita de Cássia da Silva Almico

Roberto Borges Martins

Roberto Minadeo

Rodrigo Simões

Rômulo Garcia de Andrade

Roquinaldo do Amaral

Sérgio Tadeu de Niemeyer Lamarão

Sonia Regina de Mendonça

Sydenham Lourenço Neto

Tânia Maria Ferreira de Souza

Théo Lobarinhas Piñeiro

Thiago Marques Mandarino

Vlademir José Luft

\section{REGIÃO SUL}

Alcides Goularti Filho

Armando João Dalla Costa

Ary Cesar Minella

Carlos Roberto Antunes dos Santos

Fábio Pesavento

Fernando Franco Netto

Hugo Moura Tavares

Jorge Luiz da Cunha

José Gabriel Porcile Meirelles

José Lannes

Lafaiete Santos Neves

Luís Augusto Ebling Farinatti

Luiz Roberto Pecoits Targa

Márcia Naomi Kuniochi

Maria Heloisa Lenz

Marli Marlene Mertz

Maurício Aurélio dos Santos

Oscar Graeff Siqueira

Pedro Antonio Vieira

Pedro Cesar Dutra Fonseca

Ricardo Costa de Oliveira

Ronaldo Herrlein Júnior

Sérgio Soares Braga

Solange Regina Marin

Victor Manoel Pelaez Alvarez
Thiago Costa de Souza

\section{REGIÃO NORDESTE}

Amilcar Baiardi

Cesare Giuseppe Galvan

Damião de Lima

Denise Mattos Monteiro

Eduardo Girão Santiago

Fernando Cardoso Pedrão

Jean Baptiste Nardi

José Alberto Bandeira Ramos

José Antonio Gonçalves dos Santos

José Haroldo Aguiar Junior

José Mario dos Santos Resende

Josemir Camilo de Melo

Josué Modesto dos Passos Subrinho

Marcos Guedes Vaz Sampaio

Maria José Rapassi Magalhães

Pedro de Almeida Vasconcelos

\section{REGIÃO NORTE}

Carlos Augusto de Castro Bastos

Fábio Carlos da Silva

Fabio Robson Casara Cavalcante

Roberto Araújo Oliveira Santos

Siméia de Nazaré Lopes

REGIÃO SÃO PAULO

Adalton Franciozo Diniz

Adelir Weber

Ademir Gebara

Agnaldo de Sousa Barbosa

Agnaldo Valentin

Alceu de Arruda Veiga Filho

Alexandre Macchione Saes

Alexandrine Brami-Celentano

Amaury Patrick Gremaud

Ana Lúcia Duarte Lanna

Angelita Matos Souza

Antonio Penalves Rocha

Augusto da Silva

Benedicto Heloiz Nascimento

Bernardo Gouthier Macedo

Carlos Alberto Cordovano Vieira

Carlos de Almeida Prado Bacellar
Carlos Eduardo de Freitas Vian

Carlos Eduardo Ferreira de Carvalho

Claudia Heller

Eduardo Barros Mariutti

Eliana Tadeu Terci

Ema Elisabete Rodrigues Camillo

Erika da Cunha Ferreira Gomes

Fábio Alexandre dos Santos

Fábio Antonio de Campos

Fabio Ricci

Fausto Saretta

Fernando Antonio Abrahão

Fernando Antônio Novais

Fernando Cézar de Macedo Mota

Fernando Teixeira da Silva

Flávio Azevedo Marques de Saes

Flávio Estévez Calife

Flávio Mesquita Saraiva

Francisco Luiz Corsi

Francisco Vidal Luna

Gilval Mosca Froelich

Guilherme Augusto Malagolli

Guilherme da Rosa Oliveira

Guilherme Grandi

Helder Sebastião Alves dos Reis

Helena Carvalho de Lorenzo

Heloisa Maria Teixeira

Hernan Enrique

Hernani Maia Costa

Hilário Domingues Neto

Horácio Gutiérrez

István Jancsó †

Jacob Gorender

Jacques Marcovitch

Jaeder F. Cunha

John Henry Schulz

Jonas Rafael dos Santos

José Flávio Motta

José Jobson de Andrade Arruda

José Jonas Almeida

José Marcos Nayme Novelli

José Ricardo Barbosa Gonçalves

José Sebastião Witter

Joseph Cesar Ferreira de 
Almeida

Josiane de Araujo Francelino Julio Cesar Bellingiere

Julio Manuel Pires

Lelio Luiz de Oliveira

Ligia Maria Osório Silva

Lilia Inês Zanotti de Medrano

Luciana Suarez Lopes

Luzia Monteiro Araújo Soares

Marco Aurélio Barbosa de Souza

Maria Alice Rosa Ribeiro

Maria Angélica Borges

Maria Aparecida de Paula Rago

Maria Christina Siqueira de Souza Campos

Maria Irene de Queiroz Ferreira Szmrecsányi

Maria Isabel Basilisco Celia Danielli

Maria Lucia Caira Gitahy

Maria Lucia Lamounier

Maria Lucilia Viveiros Araújo

Maria Sylvia Macchione Saes

Maria Thereza Miguel Peres
Mario Sérgio de Mattos Stipp

Michel Deliberali Marson

Mivaldo Messias Ferrari

Oriowaldo Queda

Orlando José Bolçone

Palmira Petratti Teixeira

Paula Regina Pavon

Paulo Cesar Gonçalves

Paulo Roberto Beskow

Pedro Paulo de Abreu Funari

Pedro Paulo Zahluth Bastos

Pedro Ramos

Ramón Vicente García Fernández

Raquel Glezer

Regina Celia Faria Simões

Regina Maria D'Aquino Fonseca Gadelha

Renata Cipolli D'Arbo

Renato Leite Marcondes

Renato Perim Colistete

Ricardo Zimbrão Affonso de Paula

Rogério Naques Faleiros
Rosângela de Lima Vieira

Rosângela Ferreira Leite

Rubem Roberto Sawaya

Rui Cesar de Andrade Caetano

Rui Guilherme Granziera

Sebastião Neto Ribeiro Guedes

Sérgio Salomé Silva

Silvia Fernanda de Mendonça

Figuerôa

Suzana Cristina Fernandes

Tatiana Pedro Colla Belanga

Thiago de Novaes França

Thiago Fontelas Rosado Gambi

Tomás Rafael Cruz Cáceres

Vera Lucia Amaral Ferlini

Vera Mariza H. de Miranda Costa

Vicente Contador

Vitoria Saddi

Wilma Peres Costa

Wilson Suzigan

Wilson Vieira

Wolfgang Lenk

Zoia Vilar Campos 
Receba de graça a revista História Econômica \& História de Empresas tornando-se membro da Associação Brasileira de Pesquisadores em História Econômica - ABPHE -

Nome completo:

Condição: estudante ( ) profissional ( )

CPF:

Nº. RG/Órgão emissor:

Instituição/Função:

Título acadêmico mais recente/Instituição:

Temas/Pesquisa:

Projeto/Pesquisa atual:

Publicação recente:

E-mail:

Endereço residencial:

Telefone:

Endereço comercial:

Telefone:

Endereço para correspondência: residencial ( ) comercial ( )

de de

Assinatura

SÓCIOS APRESENTANTES

Nome/Assinatura

1.

2 .

3

http://www.abphe.org.br/abphe\%20inscricao.htm 
